\title{
Lake level changes in the Tibetan Plateau from Cryosat-2, SARAL, ICESat, and Jason-2 altimeters
}

\author{
Cheinway Hwang ${ }^{1, *}$, Yung-Sheng Cheng ${ }^{1}$, Wan-Hsin Yang $^{1}$, Guoqing Zhang ${ }^{2}$, Yong-Ruei Huang ${ }^{1}$, \\ Wen-Bin Shen ${ }^{3}$, and Yuanjin Pan ${ }^{3}$ \\ ${ }^{1}$ Department of Civil Engineering, National Chiao Tung University, Hsinchu, Taiwan \\ ${ }^{2}$ Institute of Tibetan Plateau Research, Chinese Academy of Sciences, Beijing, China \\ ${ }^{3}$ School of Geodesy and Geomatics, Wuhan University, Wuhan, China
}

\begin{abstract}
Article history:
Received 26 February 2018

Revised 29 May 2018

Accepted 9 July 2018

Keywords:

Cryosat-2, GRACE, Lake level change, Lake outburst, SARAL,

Tibet Plateau

Citation:

Hwang, C., Y.-S. Cheng, W.-H. Yang, G. Zhang, Y.-R. Huang, W.-B. Shen, and Y. Pan, 2019: Lake level changes in the Tibetan Plateau from Cryosat-2, SARAL, ICESat, and Jason-2 altimeters. Terr. Atmos. Ocean. Sci., 30, 33-50, doi: 10.3319/ TAO.2018.07.09.01
\end{abstract}

\begin{abstract}
Lake level change in the Tibetan Plateau is an important indicator for regional and global climate changes. We use altimeter data from Cryosat-2, SARAL, ICESat, and Jason-2 to detect lake level changes at different spatial and temporal resolutions over 2003 - 2017 (Jason-3 data in 2017 for validation). Cryosat-2's SARIn mode provides precise water level time series over 59 lakes. SARAL's waveforms are retracked to generate near monthly, high-quality measurements at 31 lakes. Jason-2 provides a reference for removing inter-altimeter biases, enabling coherent records over lakes with Jason-2 passes. After a decade of rise since the ICESat record of 2003, the lake levels of Nam Co, Selin Co, Ngangzi Co, and Chibuzhang Co became flat in 2014 - 2016 and started to fluctuate or decline after 2016. Such positive-flat-negative trends are consistent with the trend variations of mass change from Gravity Recovery and Climate Experiment (GRACE). SARAL detected persistent lake level declines over 2013 - 2016 in southern Tibet that may signify the onset of decadal reduced flows of the Yarlung Tsangpo and Brahmaputra River that could affect the water supply for their downstream regions in India and Bangladesh. Cryosat-2 and Jason-2 detected sudden lake level rises and falls around Zhuonai, Kusai, and Salt Lake associated with a 2011 lake outburst, which is confirmed by lake volume changes from two Landsat-7 images. With a careful processing and calibration, multiple altimeters allow for determining and cross-validating long-term and episodic lake level changes unachievable by a single altimeter.
\end{abstract}

\section{INTRODUCTION}

The Tibetan Plateau (TP) is covered with numerous large natural lakes, especially in the Inner TP. The space and time evolutions of lakes here are mostly the results of local and global hydrological changes, which are often interpreted as a manifestation of regional and global climate change (Kang et al. 2010; Hwang et al. 2011; Liao et al. 2013; Crétaux et al. 2016; Zhang et al. 2017a). However, due to the vastness and remoteness of the TP, most lakes here lack in situ measurements of water level, making it difficult to understand the long-term spatial and temporal characteristics of their evolution and dynamics.

This difficulty of sampling lake level changes in the TP

\footnotetext{
* Corresponding author

E-mail:cheinway@mail.nctu.edu.tw
}

can be reduced by using measurements from remote-sensing sensors. Several remote sensing techniques have shown how lakes in the TP evolve over space and time (Zhang et al. $2011,2013,2014,2017 a, b)$. One technique is based on optical imagery from satellites or aircrafts (recently, unmanned aerial vehicles), which is typically used to detect lake area changes (Zhang et al. 2014, 2017a). Sample studies using satellite imagery in the TP are Shao et al. (2008), Huang et al. (2012), and Yao et al. (2013). Another remote technique is satellite altimetry, which can measure lake levels and their changes. There are numerous studies documenting satellite altimeter results of lake level changes in Tibet. For example, Zhang et al. (2011) used Ice, Cloud, and the land Elevation Satellite (ICESat) data to determine Tibetan lake level changes from 2003 to 2009 , concluding that the overall lake 
levels were on the rise. Kleinherenbrink et al. (2015) used Cryosat-2 (C2) data to detect lake level changes in Tibet and Tianshan area, which were then assessed by the result from Jason-2 (J2). A recent study by Jiang et al. (2017) using $\mathrm{C} 2$ suggests that $68.6 \%$ of the lakes underwent rising lake level trends. In these studies, seasonal lake levels were not statistically significant because ICESat and C2 observe lake levels at time intervals exceeding one month or longer.

By contrast, seasonal lake level changes can be easily detected by repeat altimeter missions. For example, Zhang et al. (2015) used altimeter data from the 10-day repeat TOPEX/ Poseidon (T/P) mission and 35-day repeat Envisat mission to determine lake level changes of Zhari Nam Co, showing that lake level oscillations in springs and winters were much larger than the oscillations in summers and falls. Hwang et al. (2016) used T/P-family satellites to observe seasonal and two decades of lake level changes at 23 lakes in Tibet. Crétaux et al. (2016) used satellite altimetry to calculate lake water storage changes in Tibet in order to study their interannual variability. Finally, Tseng et al. (2016) used data from ICESat, J2, and Envisat to detect the long-term variations of lake level over Dorsoidong and Chibuzhang Co, suggesting that the two lakes were merged due to the rising runoffs from the nearby glaciers near Mt. Tanggula.

These altimeter studies in the TP suggest that both long-period and short-period missions can be used for lake level changes, despite their shortcomings in either spatial or temporal resolution. Missions such as ICESat and C2 can greatly increase spatial coverages, but they were unable to detect seasonal changes over small lakes. Missions such as T/P and Envisat can provide lake level observations at 10- and 35-day intervals, but their spatial coverages are low because of the large cross-track intervals of 315 and $75 \mathrm{~km}$ of the two missions. In general, the order of decreasing spatial resolution is: $\mathrm{C} 2>$ ICESat $>$ Envisat or SARAL/AltiKa (SA) $>\mathrm{T} / \mathrm{P}$ satellites, while the order of decreasing temporal resolution is T/P satellites $>$ Envisat or $\mathrm{SA}>\mathrm{C} 2>$ ICESat. Therefore, the best strategy is combing altimeters of different mission characteristics to increase both the spatial and temporal resolutions. According to Crétaux et al. (2009), Fu and Haines (2013), and Hwang et al. (2016), we need to remove inter-altimeter biases to obtain coherent, continuous lake level observations when using multiple satellites. Such biases may be identified using in situ height measurements, but only few lakes in the TP are equipped with lake gauges (Zhang et al. 2017a, b).

In addition to long-term lake level records from multiple altimeters, another issue is the reliability and interpretation of altimeter-detected episodic lake level changes caused by extreme events such as flooding and glacier avalanche. For example, J2 detected a sudden, large lake level rise over Kusai Lake caused by an extreme precipitation event (Hwang et al. 2016), but J2 alone cannot show how Kusai Lake received the water from its upstream lakes, nor its' lake level measurements can reveal volume changes of lakes around here.

With the background analysis, this study focuses on the value of multiple altimeters in detecting both the longterm ( $>$ the time span of one mission) and short-term (few months) lake level changes in the TP. The first objective is to determine lake level changes from $\mathrm{C} 2, \mathrm{SA}, \mathrm{J} 2$, and ICESat, and examine how such results reveal long-term lake level trends and how such trends are compared with the mass change trends from GRACE (Tapley et al. 2004). The second objective is to show how multiple altimeters and Landsat-7 imagery can identify source waters contributing to the 2011 lake outburst event in northern Tibet (Hwang et al. 2016).

\section{DATA AND METHODS}

\subsection{Altimeter Data}

C2 was launched by the European Space Agency (ESA) on 8 April 2010 and has a repeat period of 369 days in its main cycles and a 30-day repeat period in its sub-cycles. C2 carries a Ku-band SAR/Interferometric Radar Altimeter to measure ranges between the satellite and the earth's surface in three different modes, i.e., the Low Resolution Mode (LRM), Synthetic Aperture Radar (SAR), and SAR/ Interferometric Radar Altimeter (SARIn) mode (Bouzinac 2013). Over the most TP, C2 uses the SARIn mode to measure surface heights, resulting in a much higher resolution than that in the LRM mode. The C2 data used in this study were downloaded from the site at $\mathrm{ftp}$ ://science-pds.cryosat. esa.int, spanning from April 2010 to June 2016.

SA is a joint mission of the Indian Space Research Organization (ISRO) and the France space agency (CNES). The mission, launched on 25 February 2013, is a continuation of the ERS series and Envisat missions. Since October 2013, SA followed exactly the ground tracks of Envisat in a 35-day repeat orbit, and carries a Ka-band altimeter, called AltiKa. The original range sampling rate of SA is $40 \mathrm{~Hz}$. A SA waveform contains 128 gates with the default tracking gate at 55. In July 2015, SA experienced an attitude control problem, resulting in ground tracks that are up to $8 \mathrm{~km}$ off SA's nominal repeat ground tracks (https://www.aviso. altimetry.fr/en/missions/current-missions/saral.html). Because of such offsets, after July 2015 SA failed to collect lake level observations over some small lakes. We downloaded the needed SA data from $\mathrm{ftp}$ ://avisoftp.cnes.fr, spanning from March 2013 to May 2016.

ICESat was launched by the National Aeronautics and Space Administration (NASA) on 13 January 2003. ICESat was part of NASA's Earth Observing System and carried the Geoscience Laser Altimeter System (GLAS) to measure surface elevations at a $40-\mathrm{Hz}$ rate. The ICESat mission ended in 2009, and it has a good performance on lake level studies of Tibet (Zhang et al. 2011). We obtained the version 34 of ICESat data from the web site: https://nsidc.org/data/ 
GLAH14/versions/34 over January 2003 to October 2009.

The J2 mission, launched on 20 June 2008, is a continuation of the T/P and Jason-1 missions. J2 is a joint mission of NASA, CNES, the European Organization for the Exploitation of Meteorological Satellites (EUMETSAT) and the National Oceanic and Atmospheric Administration (NOAA). With its 10-day repeat period, J2 provides lake measurements with the highest temporal resolution among all past and ongoing altimeters, but its large cross-track spacing results in the least number of observed lakes. The J2 data were downloaded from $\underline{\mathrm{ftp}}$ ://avisoftp.cnes.fr. The time period of the $\mathrm{J} 2$ altimeter data used spanned from June 2008 to December 2016.

\subsection{Selecting and Screening Altimeter Data}

For all altimeters, our data processing procedure is similar to the one used in Hwang et al. (2016), and is presented in three steps for the four altimeters as follows.

\section{Step 1: Selecting altimeter data over a lake water surface}

First, the Google Earth was used to determine the lake's coverage. Any altimeter data within $2 \mathrm{~km}$ to the lake's shores were ignored. Although Landsat imagery can provide a higher spatial resolution of lake boundaries, this technique was not used in the paper due to limited resources. For example, Fig. 1 shows a C2 track over Nam Co and altimeter waveforms along this track (the waveforms are not on consecutive points). For example, Fig. 1 shows a $\mathrm{C} 2$ track over Nam Co and altimeter waveforms along this track. The waveforms on land (point No. $1-3$ and 8) are corrupted and significantly different from those over Nam Co (point No. 4 - 7), which are considered usable for gener- ating lake height observations. Under this selection criterion (an altimeter observation cannot be within $2 \mathrm{~km}$ to a lake's shore), many small lakes (area $<27 \mathrm{~km}^{2}$ ) was disregarded.

\section{Step 2: Applying corrections to raw measurements}

An altimeter measures lake levels using the radar or laser ranges between the satellite and a lake's surface. Lake level measurements can be computed as (Hwang et al. 2016):

$$
\begin{aligned}
& H_{\text {lake }}=h_{\text {sat }}-R_{\text {alt }}-C \\
& C=C_{C O G}+C_{\text {wet }}+C_{\text {dry }}+C_{\text {iono }}+C_{\text {solid }}+C_{\text {pole }}+C_{\text {retrack }}
\end{aligned}
$$

Where $H_{\text {lake }}$ : ellipsoidal height of lake; $h_{\text {sat }}$ ellipsoidal height of satellite; $R_{a l t}$ : range between altimeter and lake surface; $C$ : sum of all corrections, including center of mass correction $\left(C_{C O G}\right)$, wet and dry tropospheric corrections $\left(C_{w e t}+C_{d r y}\right)$, ionospheric correction $\left(C_{\text {iono }}\right)$, solid earth tide $\left(C_{\text {solid }}\right)$, pole tide $\left(C_{\text {pole }}\right)$, and retracker correction $\left(C_{\text {retrack }}\right)$. Except $C_{\text {solid }}$ and $C_{\text {pole }}$, these corrections are satellite-dependent. Over lakes in Tibet, there is no need to apply corrections for ocean tide correction, inverse barometer correction, and sea state bias correction (Hwang et al. 2016). All corrections in Eq. (2) are provided in the altimeter datasets presented in section 2.1, except the retracker corrections for SA and J2. Currently, the data center of ICESat does not provide its waveforms for retracking, nor retracker corrections. We determined the retracker corrections for SA and J2 using the subwaveform retracking method of Yang et al. (2012). A detailed numerical procedure for this computation is already presented in Hwang et al. (2016) and will not be repeated here.

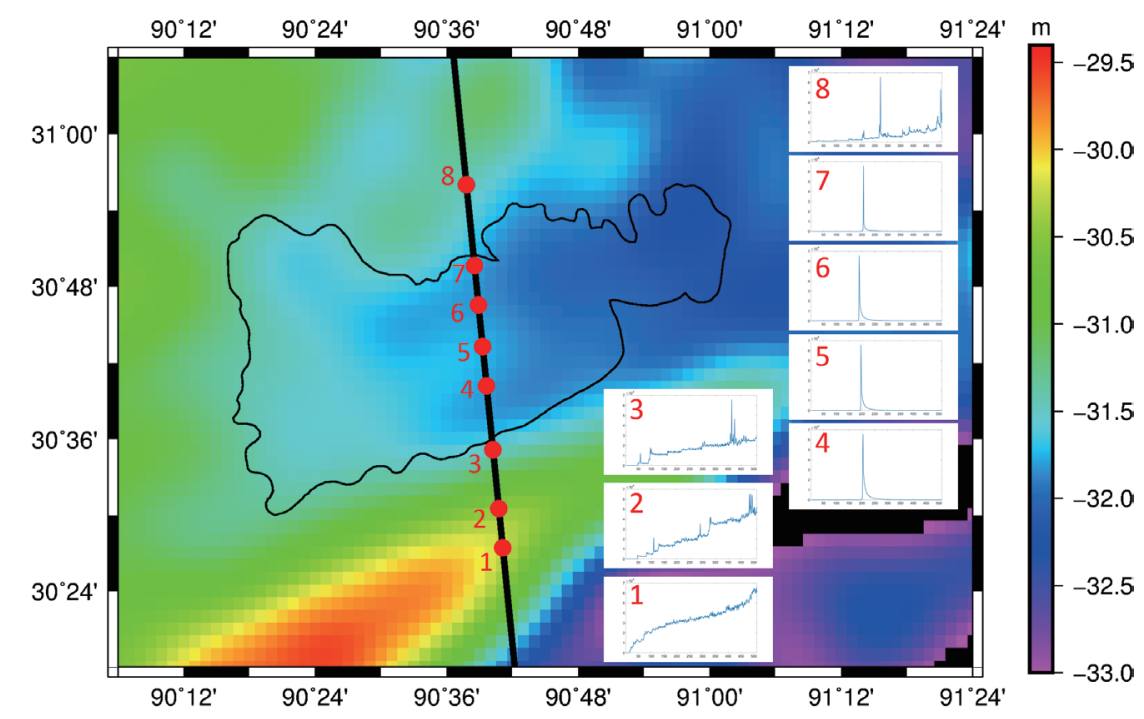

Fig. 1. A Cryosat-2 track over Nam Co with geoidal heights from EGM08. Geoidal differences on the western and eastern sides of Nam Co exceeds $1 \mathrm{~m}$. Inserted are altimeter waveforms at 8 locations over land and Nam Co's surface. The waveforms at point No.4 - 7 are specular and are considered usable waveforms. 
For $\mathrm{C} 2$, we used directly lake level observations from SGDR-L2 product, including the wet and dry tropospheric corrections, ionospheric correction, solid earth tide, pole tide, and retracker correction. The retracker corrections of Wingham/Wallis for the SARin-mode observations in the SGDR-L2 product of $\mathrm{C} 2$ can be found at https://earth.esa. int/documents/10174/1773005/C2-Evolution-BaselineCLevel2-V3.

\section{Step 3: Outlier removal}

After the data selection and the retracking correction in the previous two steps, there are still outliers in lake level observations. Such outliers can cause errors when forming mean lake levels and computing rates of lake level change (section 2.3). As such, we employed an additional step to remove outliers. Outliers are iteratively removed until all anomalies (individual observations relative to the mean of observations) fall within 2.5 standard deviations (Hwang et al. 2016).

\subsection{Correction for Geoid Gradient and Determinations of Lake Level Time Series and Trends}

Over a given lake, for each altimeter cycle or sub-cycle we formed a mean height (see $\bar{h}$ below) from the outlierfree height measurements along the ground track(s) passing the lake (see step 3 in section 2.2). Before forming the mean height, the along-track heights were reduced to heights at a reference point, which is roughly at the center of the lake [see $\left(\varphi_{0}, \lambda_{0}\right)$ below, and the latitudes and longitudes in Appendix A]. This reduction is called the geoid gradient correction. The difference between the geoidal heights at the reference point and the measurement location was computed and then added to the altimeter-determined lake level. The geoidal heights were determined from the EGM08 geoid model (Pavlis et al. 2012). The geoidal variation over a large lake can be significant. For example, Fig. 1 shows that the differences between the geoidal heights on the west coast and the east coast of Nam Co are more than $1 \mathrm{~m}$ (Jiang et al. 2017). Over a lake the size of Nam Co, the lake surface is not a surface of constant orthometric height. Neglecting geoidal differences can introduce large errors when computing the mean height from the along-track heights.

These mean lake heights are treated as "pseudo" observations over a lake and are fitted by the function:

$$
\begin{aligned}
\bar{h}\left(\varphi_{0}, \lambda_{0}, t\right)+v= & a+b\left(t-t_{0}\right)+c \cos \omega\left(t-t_{0}\right) \\
& +d \sin \omega\left(t-t_{0}\right)
\end{aligned}
$$

weight $=p$

where $\bar{h}\left(\varphi_{0}, \lambda_{0}, t\right)$ is the mean height (after the geoid gradient reduction) at the center of the lake $\left(\varphi_{0}, \lambda_{0}\right), t$ is the time for $\bar{h}$, and $t_{0}$ is the central time of a satellite mission's time span, $v$ is residual, $a$ is the mean lake level over the time span, $b$ is the rate of lake level change, $c$ and $d$ are terms for annual variation, $\omega$ is the annual frequency (one cycle per year), and $p$ is the weight for $\bar{h}\left(\varphi_{0}, \lambda_{0}, t\right)$. In this study, $p$ is the number of heights that are used to form $\bar{h}\left(\varphi_{0}, \lambda_{0}, t\right)$. It turns out the number of lake level measurements can vary from one repeat cycle to another over the same lake. In addition, $p$ is larger over a larger lake like Nam Co, where an altimeter mission may have more than one ground track and the ground track(s) can be relatively long; over a small lake, $p$ can be small because the lake may have just one short altimeter ground track.

\subsection{Constructing Inter-Satellite Lake Level Records}

This study uses four altimetry satellites to study lake level changes. These satellites use different altimeters and reference ellipsoids. Their differences are summarized as follows [see also Eqs. (1) - (2)]. (1) ICESat uses laser, while the other satellites uses pulse-limited radar. (2) J2 and C2 (conventional radar) use the Ku-band radar. (3) SA uses a Ka-band radar. (4) C2 uses the SARIn mode in the TP. (5) Ionospheric delays over lakes can be from the dual or triband altimeter measurements or from a numerical model. (6) The reference frames for different satellite missions can be different. Fu and Haines (2013) have presented a review on these differences for long-term sea level monitoring, but not for lake level monitoring.

Because of these differences between the four missions, range biases could exist between lake levels over the same spot of a lake from these four different altimeters (Crétaux et al. 2009, 2016; Fu and Haines 2013; Hwang et al. 2016). For example, Fig. 2a shows the lake level time series from three altimeters over Selin Co. Here the ICESat time series has a clear shift with respect to those from $\mathrm{C} 2$ and SA. Therefore, it will be a challenge to connect the lake measurements from ICESat, C2 and SA to form a long-term record of Selin Co's lake level changes.

One method for removing inter-altimeter biases is one that based on in situ lake gauge measurements. For example, Song et al. (2015) removed a bias between the ICESat and C2-derived lake levels over Nam Co using in situ lake level observations. In Fig. 2b, we repeat the approach of Song et al. (2015) to remove the bias between ICESat and C2 over Nam Co, where we obtained the lake gauge measurements from Zhang et al. (2011) and Song et al. (2015). The standard deviation between the $\mathrm{C} 2$ and in situ observations over the overlapping period is $0.25 \mathrm{~m}$ and the correlation is about 0.94. However, only few lakes in Tibet have in situ observations, so this method of altimeter bias removal can only be used in limited cases.

Another method of bias removal is based on comparison with the $\mathrm{J} 2$ result. $\mathrm{J} 2$ delivers highly accurate lake level measurements in Tibet, such measurements can be used to calibrate those from other satellites. However, J2 can serve 
(a)

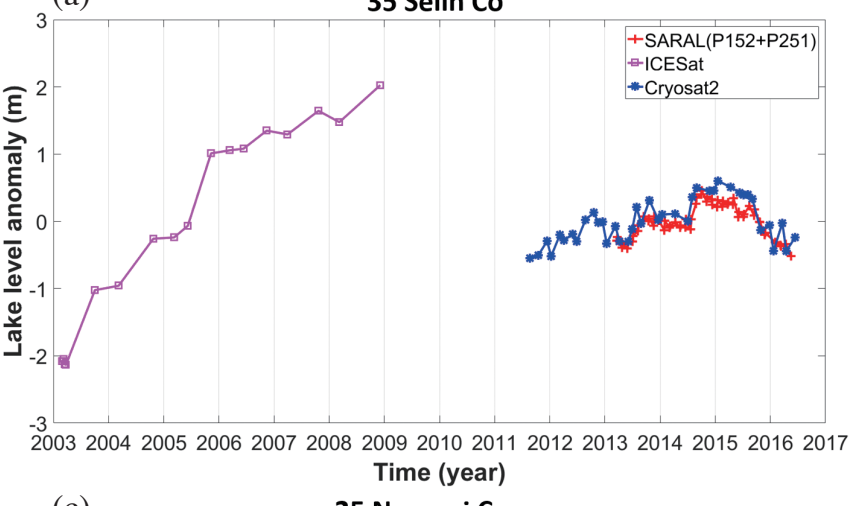

(c)

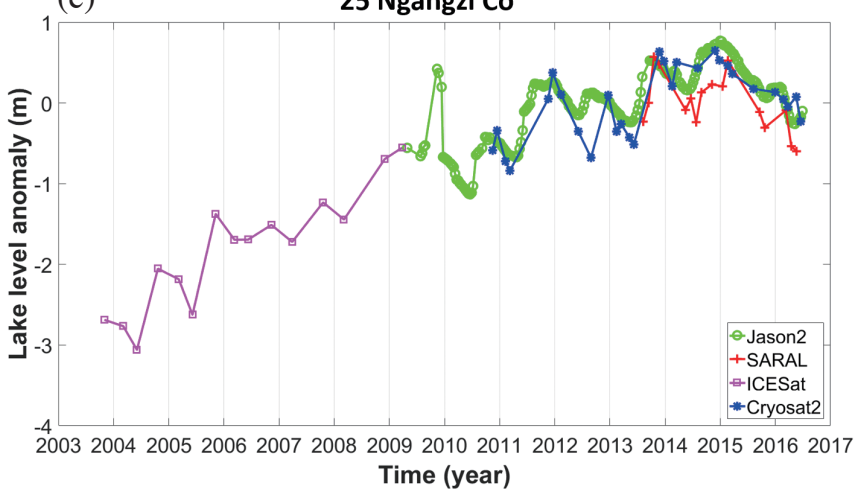

(b) 47 Nam Co

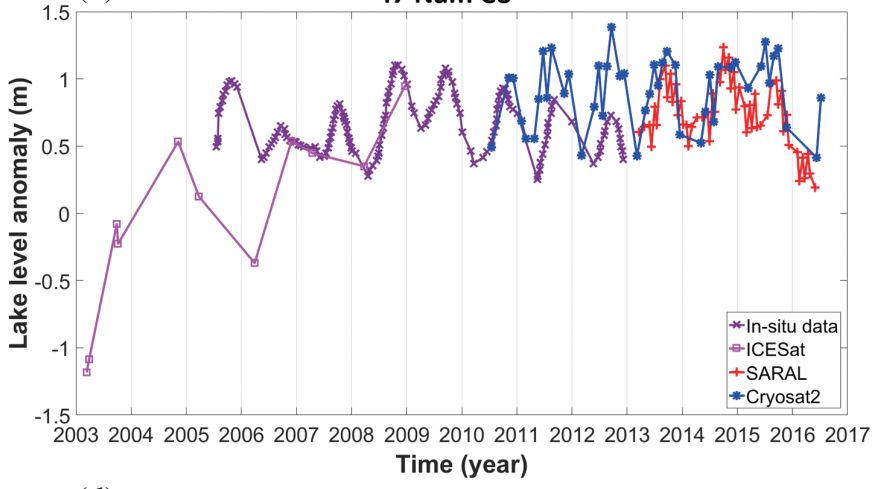

(d) 34 Dogai Coring

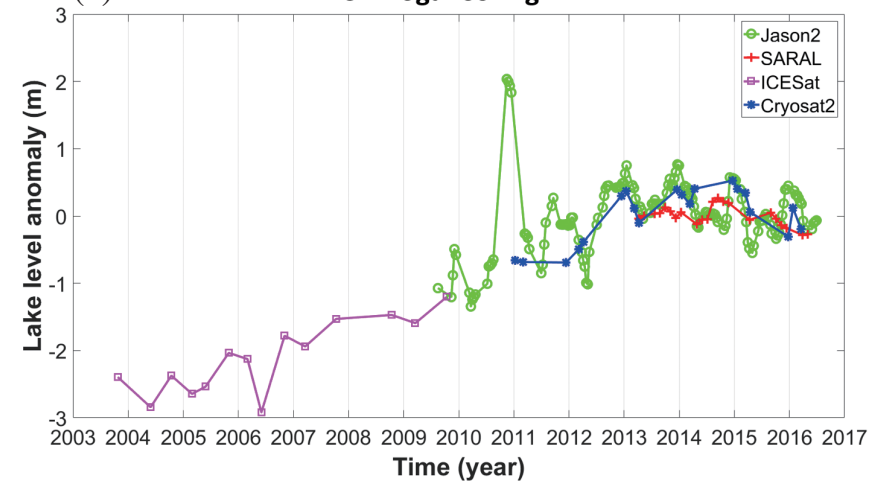

Fig. 2. (a) Lake level changes in Selin Co from three satellites, showing a large inter-satellite bias between ICESat and the other altimeters. (b) Lake level changes in Nam Co from three satellites and lake-gauge data, adjusted by in situ level measurements. Lake levels over (c) Ngangzi Co, (d) Dogai Coring, which are adjusted to the lake level measurements of Jason-2.

this function only over a lake when the lake contains at least one $\mathrm{J} 2$ track. Here we show an example of $\mathrm{C} 2$ and ICESat lake level calibrations using J2 data over Ngangzi Co (Fig. 2c). First, we determined the mean difference between ICESat and J2 lake level heights (absolute height at the same location), which is $1.72 \mathrm{~m}$. We repeated this process to obtain a mean height difference of $0.27 \mathrm{~m}$ between $\mathrm{C} 2$ and J2 over Dogai Coring (Fig. 2d). Both the results in Figs. 2c and d suggest that J2 can help to eliminate the lake level differences between ICESat and C2. Again, this bias removal is valid only if a lake is visited by $\mathrm{J} 2$.

\section{RESULT}

\subsection{Rates of Lake Level Change}

We constructed time series of lake level change from the four satellites. As comprehensive results of ICESat and J2 studies of lake level changes in the TP have been presented in, e.g., Zhang et al. (2011) and Hwang et al. (2016), we only focus on the results from the ongoing $\mathrm{C} 2$ and SA altimeters. The $\mathrm{C} 2$ altimeter data result in time series of lake level change at 59 lakes, while SA results in 31 time series. Note that we use a different altimeter data screening criterion (section 2.2) than that used in Jiang et al. (2017), leading to different numbers of selected lakes between the two studies. Appendix A provides the geodetic coordinates, areas, mean elevations of the selected lakes for the $\mathrm{C} 2$ and SA altimeters, and lake names in Chinese, English and Tibetan. The IDs for lakes in Appendix A are for convenient references in the results presented below. Of the 31 lakes with rates from SA in Appendix A, 29 lakes have rates also from $\mathrm{C} 2$. Table 1 shows the lake level trends derived from $\mathrm{C} 2$ and SA. Because an outburst event occurred over Kusai Lake in 2011 (ID 55, section 3.2), Table 1 also shows the lake's rates of water level changes over 2010 - 2012, 2012 2016, and 2010 - 2016. In general, the standard errors of the estimated rates in Table 1 are below $0.10 \mathrm{~m} \mathrm{year}^{-1}$. A sample discussion on the uncertainties of altimeter-derived rates of lake level change was presented in Gao et al. (2013); this subject will not be discussed further in this paper.

Figure 3a shows the C2-derived lake level trends over 2010 - 2016. In total, 37 lake levels were on the rise, while the lake levels at 22 lakes declined. Figure $3 \mathrm{~b}$ shows the lake level trends at the 31 lakes from SA over 2013 - 2016. Of the 31 lakes from SA, 14 were rising, while 17 were falling. Table 1 shows that over some lakes the rates from SA and C2 have opposite sign. This is partially due to the different time spans of $\mathrm{C} 2$ and $\mathrm{SA}$, and the fact that SA has a 35-day repeat period that is shorter than that of $\mathrm{C} 2$. In addition, the following two factors may contribute to the 
Table 1. Lake level change rates from Cryosat-2 (2010 - 2016) and SARAL/AltiKa (2013 - 2016) (unit: m year-1).

\begin{tabular}{|c|c|c|c|c|c|c|c|}
\hline ID $^{1}$ & Name & $\begin{array}{c}\text { Cryosat2 } \\
(2010-2016)\end{array}$ & $\begin{array}{c}\text { SARAL } \\
(2013-2016)\end{array}$ & ID $^{1}$ & Name & $\begin{array}{c}\text { Cryosat2 } \\
(2010-2016)\end{array}$ & $\begin{array}{c}\text { SARAL } \\
(2013-2016)\end{array}$ \\
\hline 1 & Aksayqin Lake & $0.20 \pm 0.04$ & - & 33 & Linggo co & $0.65 \pm 0.08$ & - \\
\hline 2 & Songmuxi Co & $0.00 \pm 0.07$ & - & 34 & Dogai Coring & $0.15 \pm 0.05$ & $-0.07 \pm 0.03$ \\
\hline 3 & Jieze Caka & $0.20 \pm 0.05$ & $0.07 \pm 0.03$ & 35 & Selin Co & $0.10 \pm 0.03$ & $0.04 \pm 0.03$ \\
\hline 4 & Gozha Co & $-0.25 \pm 0.12$ & - & 36 & Dogaicoring Qangco & $-0.01 \pm 0.04$ & $0.01 \pm 0.03$ \\
\hline 5 & La'nga Co & $-0.16 \pm 0.06$ & $-0.22 \pm 0.03$ & 37 & Jingyu Lake & $0.07 \pm 0.03$ & $0.13 \pm 0.06$ \\
\hline 6 & Mapam Yumco & $0.00 \pm 0.04$ & $-0.09 \pm 0.05$ & 38 & Dorsoidong Co & $0.40 \pm 0.06$ & $0.21 \pm 0.05$ \\
\hline 7 & Bamgdog Co & $0.62 \pm 0.02$ & $0.52 \pm 0.03$ & 39 & Botao Lake & $-0.04 \pm 0.07$ & - \\
\hline 8 & Lumachangdong Co & $0.33 \pm 0.03$ & $0.23 \pm 0.03$ & 40 & Kyebxang Co & $0.00 \pm 0.02$ & - \\
\hline 9 & Pur Co & $-0.05 \pm 0.06$ & - & 41 & Laorite Co & $-0.1 \pm 0.07$ & - \\
\hline 10 & Heishi North Lake & $0.40 \pm 0.05$ & $0.26 \pm 0.03$ & 42 & Lexie Wudan Lake & $0.36 \pm 0.03$ & $0.22 \pm .015$ \\
\hline 11 & Ngangla Ringco & $-0.06 \pm 0.02$ & $-0.17 \pm 0.03$ & 43 & Chibuzhang Co & $0.42 \pm 0.06$ & $0.20 \pm 0.05$ \\
\hline 12 & Bairab Co & $-0.02 \pm 0.02$ & - & 44 & Xijir Ulan Lake & $-0.13 \pm 0.03$ & - \\
\hline 13 & Salt Water Lake & $0.15 \pm 0.07$ & - & 45 & Wulanwula Lake & $-0.01 \pm 0.03$ & $-0.04 \pm 0.03$ \\
\hline 14 & Rinqin Xubco & $0.08 \pm 0.07$ & - & 46 & Puma Yumco & $-0.17 \pm 0.07$ & $-0.09 \pm 0.04$ \\
\hline 15 & Taro Co & $-0.09 \pm 0.02$ & $-0.31 \pm 0.05$ & 47 & Nam Co & $0.03 \pm 0.03$ & $-0.09 \pm 0.03$ \\
\hline 16 & Lagkor Co & $0.14 \pm 0.11$ & - & 48 & Mingjing lake & $0.39 \pm 0.07$ & $-0.15 \pm 0.15$ \\
\hline 17 & Yamzhog Yumco & $0.36 \pm 0.11$ & - & 49 & Taiyang Lake & $0.07 \pm 0.09$ & - \\
\hline 18 & Dong Co & $0.00 \pm 0.03$ & $-0.04 \pm 0.02$ & 50 & Zige Tangco & $0.1 \pm 0.04$ & - \\
\hline 19 & Dagze Co & $0.07 \pm 0.03$ & - & 51 & Hoh Xil Lake & $0.26 \pm 0.05$ & - \\
\hline 20 & Peiku Co & $0.03 \pm 0.04$ & - & 52 & Zhuonai Lake & $-2.06 \pm 0.52$ & - \\
\hline 21 & Zhari Nam Co & $0.01 \pm 0.01$ & $-0.11 \pm 0.03$ & 53 & Cuorendejia & $-0.13 \pm 0.09$ & $-0.03 \pm 0.08$ \\
\hline 22 & Yi’bug Caka & $-0.14 \pm 0.15$ & - & 54 & Telashi Lake & $0.25 \pm 0.05$ & - \\
\hline 23 & Yurbao Co & $0.63 \pm 0.11$ & - & 55 & Kusai Lake & $0.4 \pm 0.38$ & $-0.07 \pm 0.02$ \\
\hline 24 & Margai Caka & $0.24 \pm 0.05$ & - & & Kusai Lake (2010 - 2012) & $7.91 \pm 2.77$ & - \\
\hline 25 & Ngangzi Co & $0.12 \pm 0.04$ & $-0.20 \pm 0.08$ & & Kusai Lake (2012 - 2016) & $-0.21 \pm 0.05$ & - \\
\hline 26 & Dagze Co & $0.08 \pm 0.03$ & $0.10 \pm 0.04$ & 56 & Salt Lake & $0.78 \pm 0.06$ & - \\
\hline 27 & Urru Co & $-0.07 \pm 0.05$ & - & 57 & Gyaring Lake & $0.02 \pm 0.04$ & $-0.04 \pm 0.03$ \\
\hline 28 & Xianhe Lake & $0.19 \pm 0.05$ & - & 58 & Eling lake & $-0.19 \pm 0.08$ & $-0.19 \pm 0.05$ \\
\hline 29 & Yinbo Lake & $0.38 \pm 0.05$ & - & 59 & Donggei Cuona Lake & $0.08 \pm 0.03$ & - \\
\hline 30 & Pongyin Co & $0.03 \pm 0.05$ & - & 60 & Alake lake & - & $0.14 \pm 0.03$ \\
\hline 31 & Xuemei lake & $0.42 \pm 0.07$ & $0.15 \pm 0.03$ & 61 & Qinghai Lake & - & $0.03 \pm 0.02$ \\
\hline 32 & Gyaring Co & $-0.22 \pm 0.08$ & $-0.34 \pm 0.08$ & & & & \\
\hline
\end{tabular}




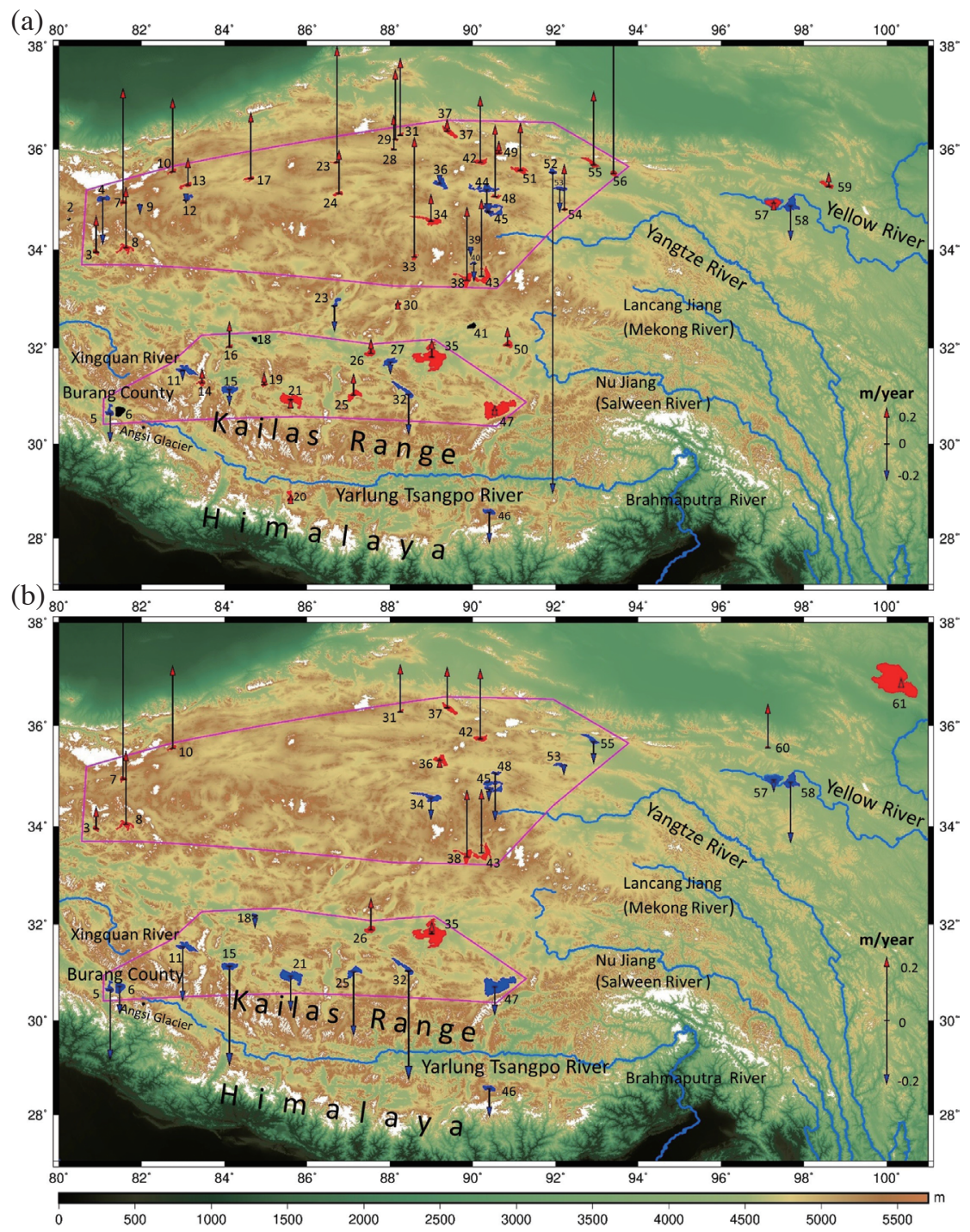

Fig. 3. Rates of lake level change from (a) Cryosat-2 at 61 lakes (2010 - 2016), (b) SARAL/AltiKa at 31 lakes (2013 - 2016). The geodetic coordinates and IDs of the lakes are shown in Appendix A. The two polygons show the boundaries for computing the trends of GRACE-derived mass changes in Fig. 5. The polygon in southern Tibet is so chosen that the Himalayas are not included.

different signs: (1) SA repeats its ground track within $1 \mathrm{~km}$ and tends to be less affected by modeled geoidal differences from EGM08 and (2) SA's data volumes are stable from one cycle to another, compared to C2's data volumes. More studies are needed to clarify the differences between $\mathrm{C} 2$ and SA over the same lakes in Table 1. Despite these differences, Figs. $3 a$ and $b$ show that, in general, the lake levels in western and northern Tibet were rising, while those in southern Tibet were falling.

\subsection{Comparisons Between Lake Level Changes from Cryosat-2 and SARAL}

In addition to Fig. 2, Fig. 4 shows the time series of lake level change from $\mathrm{C} 2$ and $\mathrm{SA}$ at selected lakes in connection to the $\mathrm{C} 2$ and SA results in Table 1 . Figure 4 also includes
Jason-3 and extended C2 records, which will be discussed in section 4.1.1. In Fig. 4, the SA-derived rates confirm the rates from $\mathrm{C} 2$, thus showing the value of a repeat mission like SA (or its sister missions like the Sentinel series, see https://earth.esa.int/web/sentinel/missions) in validating results from an altimeter mission with the characteristics of C2, or from ICESat-2 (https://icesat-2.gsfc.nasa.gov). Furthermore, in most cases the seasonal variations from $\mathrm{C} 2$ are consistent with those from SA (Fig. 2).

A large number of studies have analyzed the causes of the past and recent lake level changes in Tibet. For example, Jiang et al. (2017) found that lake level changes in Tibet were strongly related to temperature changes. Zhang et al. (2017a) attributed recent lake expansions to increased precipitations and meltwater from glaciers. In general, temperature rising rates in Tibet were 2 times more than the global average rate 
(Kang et al. 2010; Liao et al. 2013). In this study, our aim is not to repeat such lake level-climate factor analyses, which are largely based on lake level measurements up to 2014 or 2015. Instead, in section 4, we will discuss two subjects: (1) decadal lake level trends and onsets of declines over selected lakes and connections to the GRACE result, and (2) a 2011 lake outburst detected by the $\mathrm{J} 2$ and $\mathrm{C} 2$ altimetry.

\section{DISCUSSION}

\subsection{The Post-2016 Trend of Lake Level}

\subsubsection{The Decadal Change Signal: Extending Lake Level Records}

We notice that, the lake levels of Selin Co (Fig. 2a), Nam Co (Fig. 2b), Ngangzi Co (Fig. 2c), and Dogai Coring (Fig. 2d) started to decline since around 2014 - 2016 after more than a decade of lake level rise (but note the result when the Jason-3 data are added). In two previous studies (Hwang et al. 2005, 2016), it was found that the lake levels of Ngangzi Co (ID 25) have opposite trends before and after the 1997 - 1998 El Niño. The 2015 - 2016 El Niño is the largest El Niño since the 1997 - 1998 event (Levine and McPhaden 2016). Zhai et al. (2016) showed that it has affected the climate in China. Specifically, this event increased the temperatures and droughts in northern China. But whether this 2015 - 2016 event has any connections to climate change in the TP has not been reported.

The flat rates in Fig. 2 around 2014 - 2016 seem to indicate a possible onset of a new trend of lake level change in the TP, which might affect the long-term (at decadal levels or longer) supplies of source water to the major rivers originating from Tibet (Fig. 3), such as the Yangtze River, the Yellow River, and the Yarlung Tsangpo River (see more discussions using extended lake records and GRACE results below). Decadal climate variability has become increasingly important for predicting the long-term climate effect on water resource, agriculture and natural hazards (Navarra 1999; Liu 2012). As shown by Liu (2012), decadal changes can be of stochastic and deterministic nature: a stochastic decadal change can be triggered by an event such as El Niño or La Niña and has no clear onset time. A deterministic decadal change can be related to periodic phenomena such as the 11year solar cycle (Liu 2012). As it happened, the years 2014 - 2016 belong to the warm phase of the El Niño Southern Oscillation (ENSO). But it is beyond the scope of this paper to investigate whether this 2015 - 2016 El Niño has initiated the lake level decline around 2014 - 2016 seen in Fig. 2. Incidentally, recent papers dealing with Tibetan lake levels, e.g., Hwang et al. (2016) and Jiang et al. (2017), show altimeter records in Tibet only up to about 2014 and early 2015. According to the predictions of Yang et al. (2018), precipitation and lake area in the inner Tibetan Plateau will continue to increase over 2016 - 2025, but with lower rates compared to the pre-2016 rates. The post-2016 altimeter data in Tibet can provide examinations for such predictions.

Here we provide a preliminary examination of the post2016 lake level trends by extending the lake level records of three lakes in Fig. 2 and that of Chibuzhang Co to the latest possible date (note: the rates in Fig. 3 are based on altimeter data up to early 2016). Whenever possible, we also include lake level records from Jason-3 (the follow-on mission of Jason-2, launched in January 2017). Figure 4 shows the extended lake levels over lakes that have signs of the lake level decline (three lakes in Figs. 2a - c, plus Chibuzhang Co in Fig. 4d). Note that, due to a time constraint, the extension is relative to the results in Figs. 2 and 3 only; we cannot obtain altimeter data to extend the record over Dogai Coring in Fig. 2d. In Fig. 4a, we manually lowered ICESat's measurements to make a smooth transition for all the measured lake levels in Fig. 4a. The result shows that Selin Co's lake level has been rising since the beginning of ICESat's records (2003), reaching a peak in early 2015 and starting to decline after 2016. The extended $\mathrm{C} 2$ records show a continuous decline of Nam Co lake level after 2016.

The extended records from Jason-3 over Ngangzi (Fig. 4c) and Chibuzhang Co (Fig. 4d) show mixing results. Over these two lakes, the rates from J2, SA and $\mathrm{C} 2$ turn from positive values to negative values around 2014 - 2016. While Jason-3 shows fluctuating lake levels of Ngangzi Co after 2016, surprisingly it indicates that the lake level of Chibuzhang Co continues to rise after 2016. Since Chibuzhang Co receives meltwater from Mt. Tanggula, where the glaciers are rapidly retreating (Chao et al. 2017), the post2016 lake level rise of Chibuzhang Co from Jason-3 may indicate accelerated meltwater from Mt. Tanggula.

\subsubsection{Lake Level Change and Mass Change}

The post-2016 lake level trend can be compared with that of an independent parameter such as mass change. In this paper, we use mass changes derived from the GRACE gravity mission (Tapley et al. 2004) to examine a potential link between the lake level trends seen in Figs. 2 and 4 and the mass trends from GRACE. Figure 5 shows the time series of monthly mass change within the polygons (Figs. 3a and b) in northern (Fig. 5a) and southern Tibet (Fig. 5b). The two time series in Fig. 5 were conveniently obtained from the GRACE Plotter at http://www.thegraceplotter.com, where we chose the solution CSR RL05 DDK5 for the result in Fig. 5 (note: GRACE solutions on the GRACE Plotter are available up to early 2016). This solution is from the Release 5 of the GRACE Level 2 data, the Center for Space Research, at the University of Texas. The DDK5 filter was described in Kusche et al. (2009). In addition, we did not remove the effect of glacier isostatic adjustment from the GRACE-derived gravity changes, which is small in Tibet and will not exhibit any decadal trend (our targeted 
signal). In Figs. 5a and b, we also show the smoothed EWH changes by applying the Gaussian filter to the original EWH values (the filtering window size is one year).

Figure 5a shows that, in northern Tibet the trends of mass change (in equivalent water height, EWH) from GRACE were consistently positive from 2003 to 2014, with a mean rate of about $1 \mathrm{~cm} /$ year in EWH (note: a value in the time series is the areal mean within the polygon defined in Fig. 3a; the same holds for the values in Fig. 5b). The mass increase trend became flat some time near 2014 - 2016. The variation in the mass change rate in Fig. 5a appears to be similar to the variations in the lake level change rate in Figs. 2 and 4. Note that, the rates of lake level change in Fig. 3a from C2 are over 2010 - 2016, thus the signs of rates are mostly positive and are dominated by the positive changes before 2014. Because of C2's long repeat period and the resulting large uncertainties in the estimated rates, we did not show the rates of lake level change over 2013 - 2016 from C2.
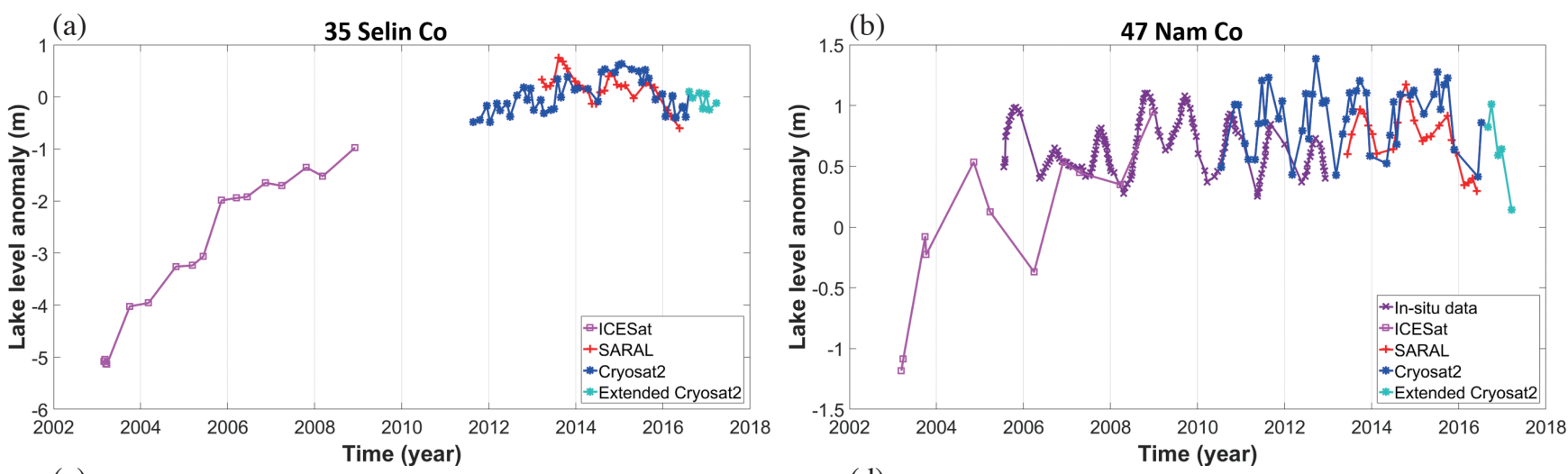

(c)

25 Ngangzi Co
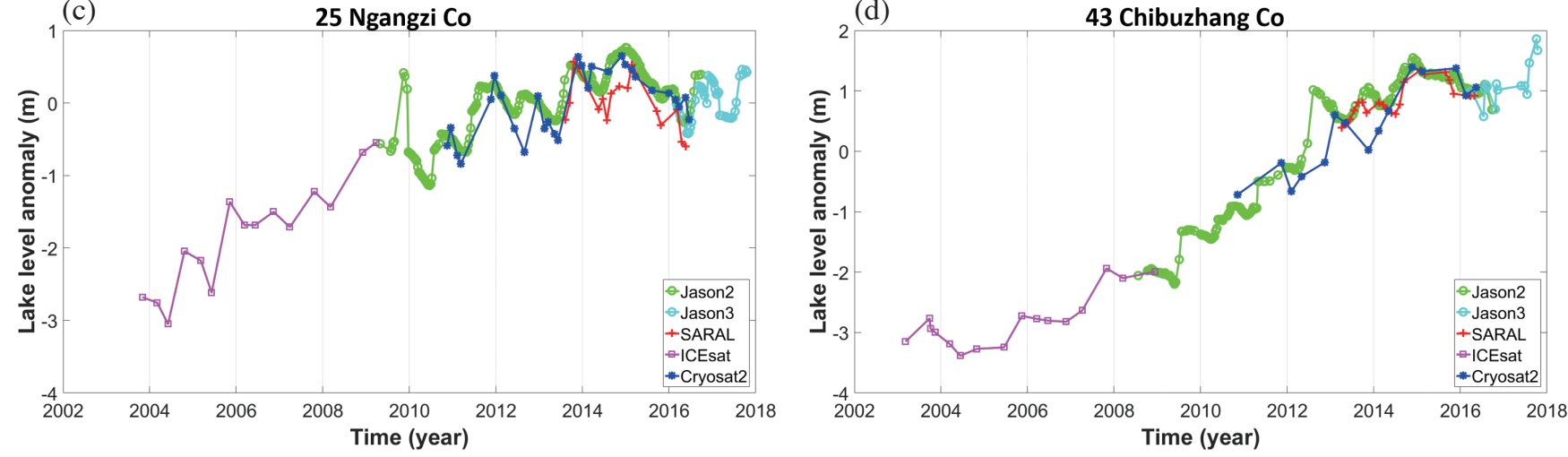

Fig. 4. Extension of lake level records from early 2016 to March 2017 from C2, J2, and Jason-3 over (a) Selin Co, (b) Nam Co, (c) Ngangzi Co, and (d) Chibuzhang Co. For coherent lake level trends, shifts are applied to the ICESat records whenever needed.
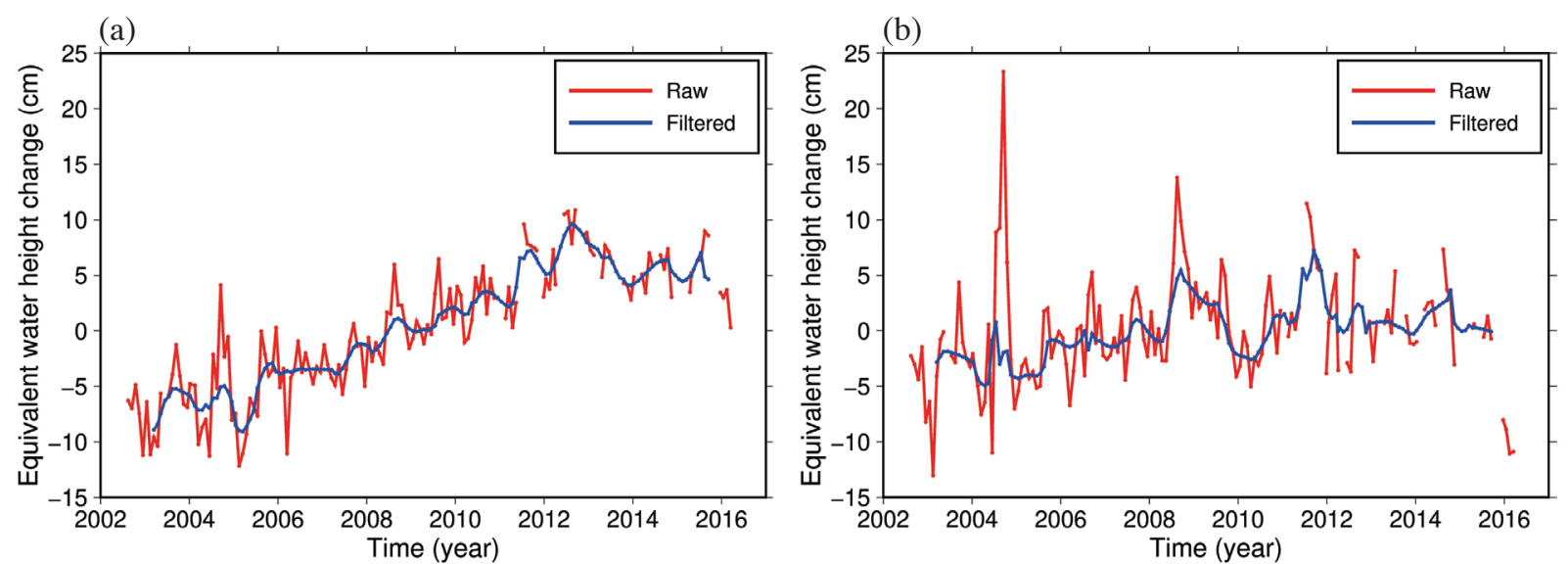

Fig. 5. Trends of GRACE-derived mass change in (a) northern Tibet (within the polygon in Fig. 3a) and (b) southern Tibet (within the polygon in Fig. 3b). 
In southern Tibet, the trends of mass change and lake level change (Figs. $3 b$ and 5b) were different from those in northern Tibet (Figs. 3a and 5a). The SA-derived lake level changes over 2013 - 2016 show negative signs (Fig. 3b; also the post-2014 lake level changes in Fig. 2), which are the results of lake level declines starting some time in 2014 - 2016 (an exact epoch for the start of the declines is not clear in Fig. 2). Like northern Tibet, southern Tibet has trends of mass change (Fig. 5b) that were persistently positive, but here the mean magnitude of mass change rate is $0.5 \mathrm{~cm}$ year ${ }^{-1}$, about half that of northern Tibet. Again, like northern Tibet the rates of mass change in southern Tibet became flat some time in 2014 and then turned to negative values during 2014 - 2016. Note that the two time series of GRACE EWH in Fig. 5 contain large gaps after 2011, which were caused by the 40 - 50 days of GRACE's instrument shutdowns since April 2011 (Tapley et al. 2015). Despite these gaps, the declines of EWH values are evident in the two time series in Fig. 5. Furthermore, the EWH time series in Fig. 5b appears to be noisier than that in Fig. 5a, which is partially attributed to a smaller area used to define the southern Tibet (see the smaller polygon in Fig. 3).

In summary, the altimeter and GRACE results show that the trends of lake level change and mass change in the entire TP were positive from 2002 to around 2014, became flat (near zero) in 2014 - 2016, and lake levels at some lakes started to decline after 2016. But it remains questionable whether such declines will sustain into the next decade or longer, which can be answered by using long altimeter and GRACE (or its follow-on) records.

\subsubsection{Lake Level Decline in Southern Tibet and the River Flows of Yarlung Tsangpo and Brahmaputra}

The discussions in sections 4.1.1 and 4.1.2 raise an important issue: can the post-2016 declines in lake level and mass change in southern Tibet have any links to the flows of the rivers originating from Tibet? (See the major rivers in Fig. 3.) Immerzeel et al. (2010) showed that, while glacier meltwater plays a modest role for the flows of Yangtze River and Yellow River, it is extremely important for the Brahmaputra River. The Brahmaputra River is a major source of water for northeastern India and Bangladesh, and its upstream is the Yarlung Tsangpo River in southern Tibet (Fig. 3). The Yarlung Tsangpo River receives glacier meltwater from the Kailas Range to its north and from the Himalayas to its south. The lakes in southern Tibet (Fig. 3b) are mostly endorheic (Zhang et al. 2017b) and receive water from the Kailas Range and other sources. The Kailas Range is located between 78 and $90^{\circ} \mathrm{E}$ ), and is at the northern side of the valley containing the entire Yarlung Tsangpo River (Fig. 3; see also search results by Baidu and http:// www.igsnrr.ac.cn/kxcb/dlyzykpyd/zgdl/zgdm/200704/ t20070424 2154874.html). Since glaciers over the Kailas Range contribute meltwater to both the Yarlung Tsangpo River and the lakes in southern Tibet (Fig. 3), the onset of the decadal lake level decline and mass decline discussed in sections 4.1.1 and 4.1.2 may imply the beginning of a long-term (at least one decade) reduced flows of the Yarlung Tsangpo River and the Brahmaputra River due to less meltwater from the Kailas Range.

Because of the potential reduction of river flow in the Yarlung Tsangpo River, here we discuss the lake levels of La'nga Co and Mapam Yumco (IDs 5 and 6, Fig. 3). One of the glaciers that feed the two lakes is the Angsi Glacier, which is the origin of the Yarlung Tsangpo River (https:// en.wikipedia.org/wiki/Angsi Glacier). La'nga Co also receives inflows from the Xingquan River west of La'nga, which receives meltwater from glaciers in the Himalayas and the western Kailas Range. The Angsi Glacier is located at Burang County in southern Tibet, with latitude $30.2959^{\circ} \mathrm{N}$ and longitude $81.1772^{\circ} \mathrm{E}$. In addition, subsurface caves and channels may exist between the two lakes, allowing Mapam Yumco to supply water to La'nga Co, which is at a lower altitude. The lake level of La'nga Co has been declining monotonically since the start of the T/P record in October 1992 (Hwang et al. 2016). The lake level of Mapam Yumco is governed by the glacier melt in the catchment area in its south (Biskop et al. 2016). Figures $6 a$ and $b$ show the time series of lake level change over La'nga Co and Mapam Yumco from $\mathrm{C} 2, \mathrm{~J} 2$, and SA. The current rates of lake level change of Mapam Yumco are $-0.09 \mathrm{~m}_{\text {year }}^{-1}$ from SA and $-0.01 \mathrm{~m}_{\text {year }}{ }^{-1}$ from $\mathrm{C} 2$ (no $\mathrm{J} 2$ result in Mapam Yumco). This implies that the lake level of Mapam Yumco is relatively steady compared to that of La'nga Co, which is $-0.22 \mathrm{~m}_{\text {year }}{ }^{-1}$ from SA and $-0.16 \mathrm{~cm} \mathrm{year}^{-1}$ from $\mathrm{C} 2$. These results show that the lake level of La'nga $\mathrm{Co}$ is declining much faster than that of Mapam Yumco. In summary, the declining lake levels of the two lakes, together with the negative lake level rates in southern Tibet from SA (Fig. 3b), may signify decreasing glacier meltwater in southern Tibet and a potential decreased runoff of the Yarlung Tsangpo River that in turn reduces the flow of the Brahmaputra River.

\subsection{The 2011 Lake Outburst Around Kusai Lake: Validation by Satellite Imagery}

Here we discuss the large positive rate over Kusai Lake (No. 55) in Fig. 3. This rate is associated with a sudden lake level rise that has been detected by the $\mathrm{J} 2$ altimeter (Hwang et al. 2016). However, no remote sensing data were used to explain the sudden rise. According to Liu et al. (2016), two strong rainfall events near 22 August 2011 may have led to the lake level rise over Kusai. After these two events, persistent rainfalls continued in 2011 to raise the lake level of Zhuonai Lake, which is located in the upstream of Kusai. The strong rains and two major earthquakes combined to 
induce the outburst of Zhuonai Lake, which caused the large lake level rises at Kusai and Salt Lakes.

Here we use the altimeter data from $\mathrm{C} 2$ and $\mathrm{J} 2$ as well as satellite imagery to investigate this 2011 lake outburst event. First, Fig. 7 shows the locations of the lakes around Kusai. Zhuonai Lake is in the upstream of Kusai, providing source water to the latter. East of Kusai lie two major lakes, Haidingnuover Lake and Salt Lake. Figure 8 shows two Landsat-7 images around Kusai Lake and Salt Lake on 23 November 2010 (before the outburst) and 12 November 2012 (after the outburst). These two images were obtained from United States Geological Survey (USGS) public site (https://earthexplorer.usgs.gov). To avoid the seasonal variation over the lake, we chose two images in the same season to minimize errors in estimating lake volume changes. It is clear that the two images show different lake coverages due to the flooding related to the lake outburst.

The J2 satellite travels through only Kusai Lake, rather than Zhuonai and Salt Lakes, making J2 unable to detect the consequence of Zhuonai's lake outburst (i.e., the sudden rise of Kusai lake level). That is, J2 alone cannot see both the cause and consequence of the outburst of Zhuonai. On the other hand, because $\mathrm{C} 2$ passes over the three lakes, $\mathrm{C} 2$ 's lake level observations can explain the origin and the result of the lake outburst. Figure 9 shows the C2-derived lake level changes over Zhuonai, Kusai and Salt Lakes, indicat- ing dramatic lake level drops of Zhuonai Lake (Fig. 9a) and sudden level rises over Kusai and Salt Lakes (Figs. 9b and c) in 2011, which are consistent with the result of Liu et al. (2016). We find that (by C2) the height of Zhuonai Lake declined by $12.6 \mathrm{~m}$ after the outburst. In contrast, the heights of Kusai and Salt Lakes rose by $6.0 \mathrm{~m}$ (the mean of the C2 and $\mathrm{J} 2$ results) and $14.8 \mathrm{~m}(\mathrm{C} 2)$, respectively.

Using the two images in Fig. 8 and the lake level changes from $\mathrm{C} 2$ and $\mathrm{J} 2$, we computed the volume changes of Zhuonai, Kusai, and Salt Lakes as follows. First, we determine whether a pixel in the images is over lake water using the modified normalized difference water (MNDWI) index (Xu 2006):

$M N D W I=\frac{G-M I R}{G+M I R}$

where $G$ is the Green-band value and MIR is the middle infrared-band value. The pixels over lake water were then used to compute the lake areas from the two images (Table 2). Our result shows that, Zhuonai Lake lost an area of $111.9 \mathrm{~km}^{2}$ due to the outburst, while Kusai and Salt Lakes gained areas of 42.8 and $81.4 \mathrm{~km}^{2}$.

The changes in lake level (Fig. 9) and lake area (Table 2) were then used to determine the changes in volume
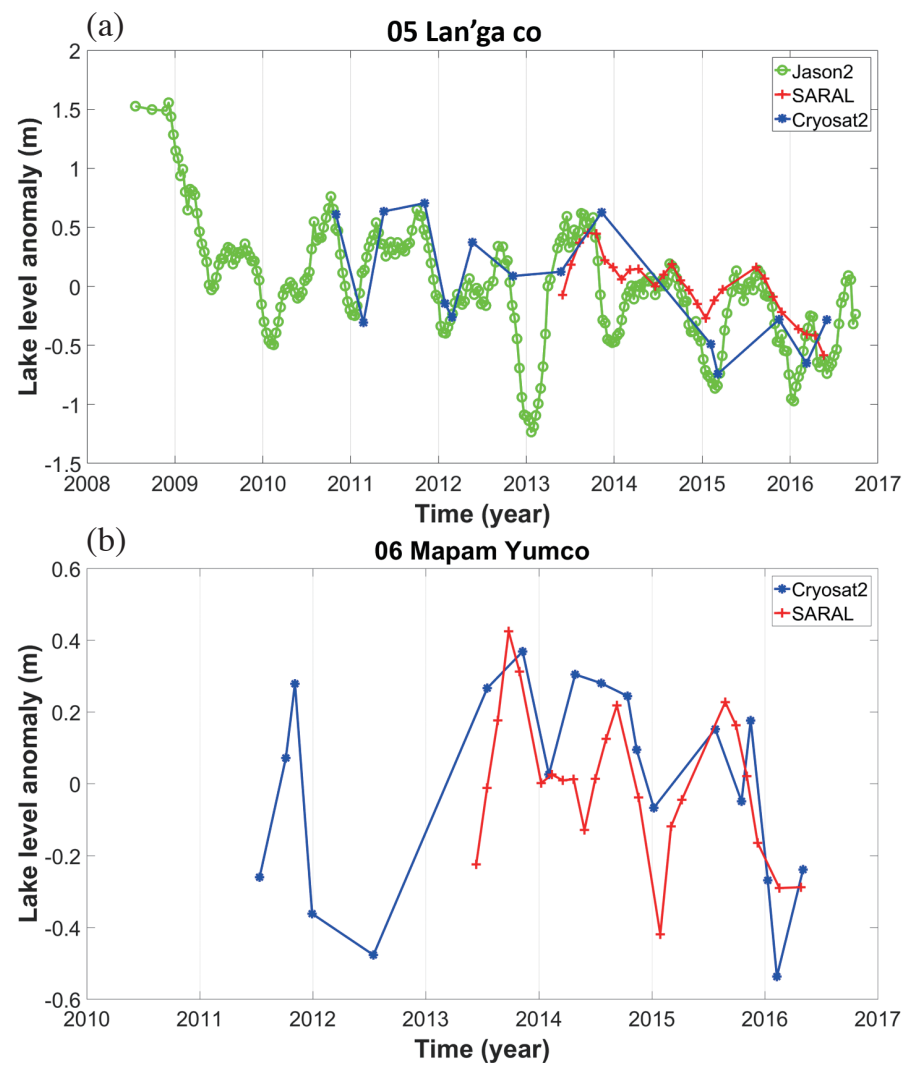

Fig. 6. Time series of lake level change over (a) La'nga Co and (b) Mapam Yumco. 


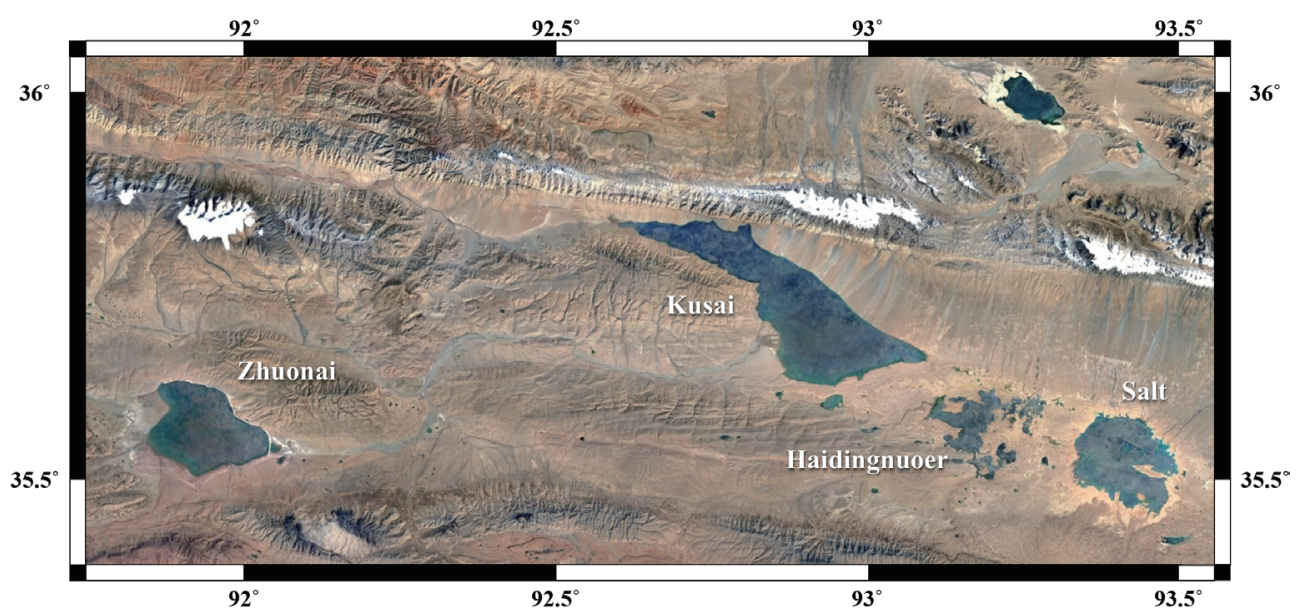

Fig. 7. Locations of Zhuonai Lake, Kusai Lake, Salt Lake, and Haidingnuoer Lake from the Google Earth. The frame of latitude and longitude is added by the authors of this paper.

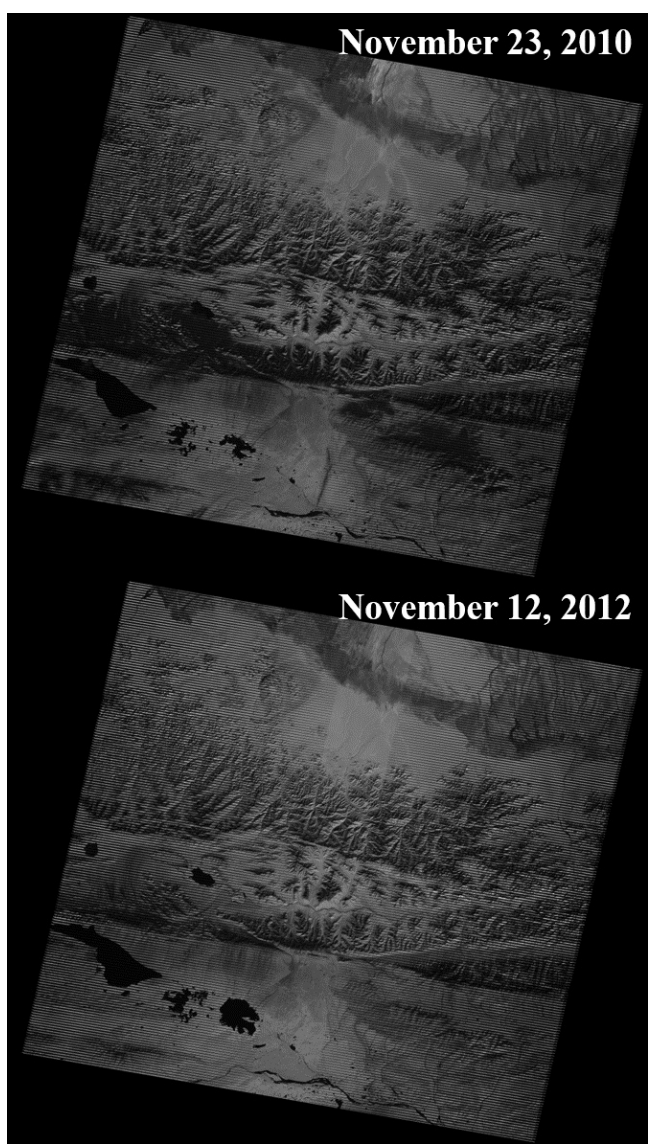

Fig. 8. Landsat-7 images of Kusai and Salt Lakes on 23 November 2011 and 12 November 2012, showing different lake coverages before and after the 2011 lake outburst. 

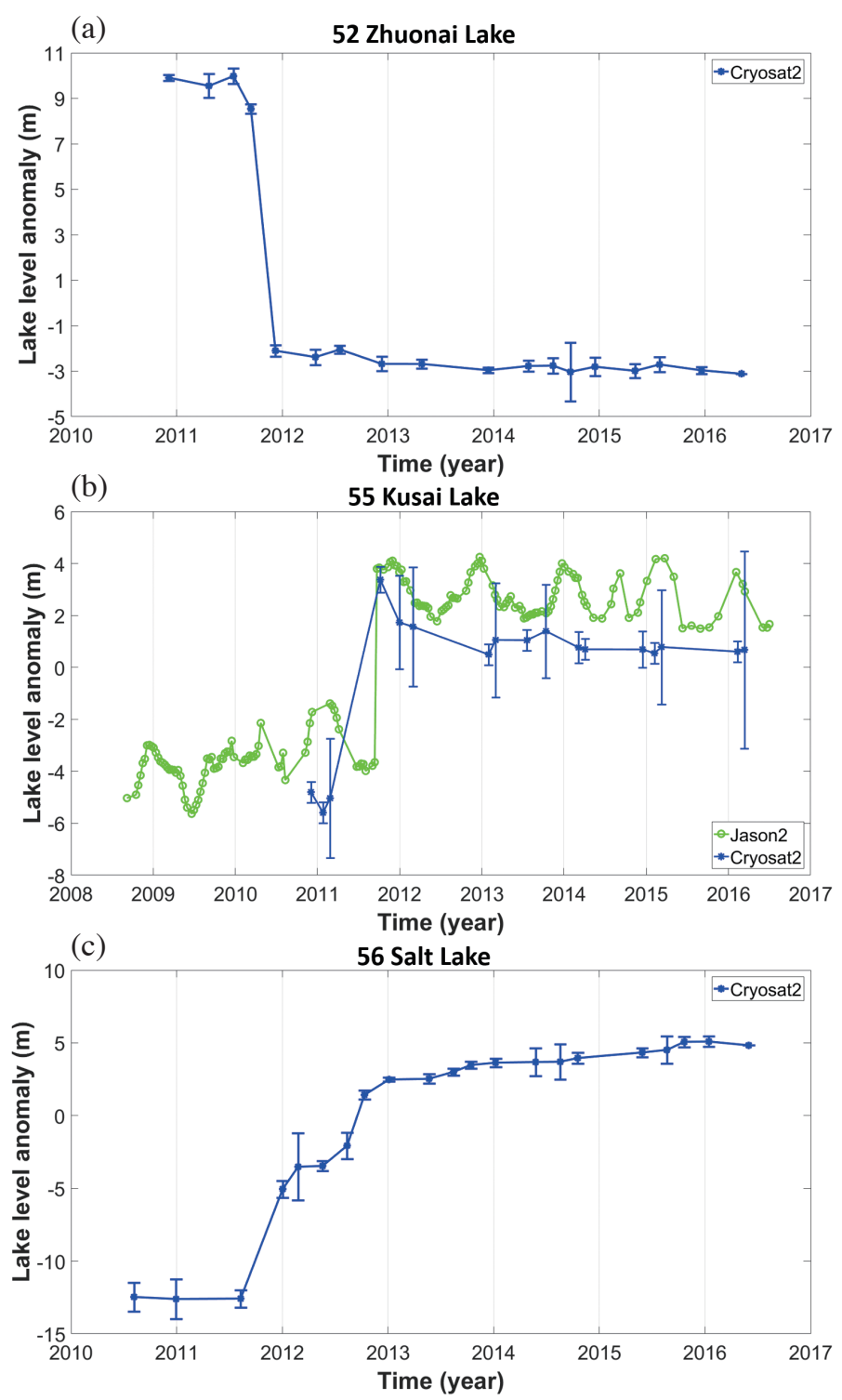

Fig. 9. (a) Drops of Zhuonai lake level in 2011 from Cryosat-2. (b) Rises of Kusai lake level from Cryosat-2 and Jason-2. (c) Rises of Salt lake level from Cryosat-2. The error bars correspond to the $68 \%$ confidence level (one sigma).

Table 2. Change of Zhuonai Lake area before and after the lake outburst (unit: $\mathrm{km}^{2}$ ).

\begin{tabular}{ccccc}
\hline ID & Lake & Area (before outburst) & Area (after outburst) & Times of images (before/after) \\
\hline 52 & Zhuonai Lake & \multirow{2}{*}{253.8} & 152.2 & $\begin{array}{l}2010 / 12 / 16 \\
2012 / 11 / 03\end{array}$ \\
\hline 55 & Kusai Lake & \multirow{2}{*}{275.3} & 327.2 & $\begin{array}{l}2010 / 12 / 16 \\
2012 / 11 / 03\end{array}$ \\
\hline 56 & Salt Lake & \multirow{2}{*}{47.8} & \multirow{2}{*}{129} & $\begin{array}{l}2010 / 11 / 23 \\
2012 / 11 / 12\end{array}$ \\
\hline
\end{tabular}


by two methods as follows (Taube 2000; Crétaux et al. 2016; Jiang et al. 2017):

$$
\begin{aligned}
& \Delta V_{1}=\frac{1}{3}\left(H_{2}-H_{1}\right) \times\left(A_{1}+A_{2}+\sqrt{A_{1} \times A_{2}}\right) \\
& \Delta V_{2}=\frac{1}{2}\left(H_{2}-H_{1}\right) \times\left(A_{1}+A_{2}\right)
\end{aligned}
$$

where $\Delta V_{1}$ and $\Delta V_{2}$ volume change by the two methods, $H_{1}$ and $H_{2}$ are the lake levels before and after the lake outburst, and $A_{1}$ and $A_{2}$ are the areas before and after the outburst (Table 2). The first method [Eq. (6)] is more rigorous than the second method (Taube 2000).

Table 3 shows the volume changes using Eqs. (5) and (6). Both methods lead to the result that the sums of the three lake volume changes are not zero. This can be explained below. First, not only Kusai Lake and Salt Lake received runoff water from Zhuonai Lake, but also Haidingnuoer Lake, which is a small lake between Kusai Lake and Salt Lake. The original Salt Lake merged other minor lakes around it to quickly expand its area. As a result, the area and the positive lake volume may be overestimated. In addition, the times associated with the satellite images can influence the estimation of volume changes: their times may not exactly correspond to the times finalizing the net effect of water loss (Zhuonai Lake) and gain (Kusai Lake and Slat Lake). Lake shore gradients may also affect the extents of lake level changes, thereby affecting estimates of lake volume change. In general, under the same lake volume change, a gentle shore gradient will result in a less lake level change, compared to a steep shore gradient (Huang et al. 2012). In addition, the suddenly expanded areas of Kusai Lake and Salt Lake could be over shallow-water areas, which can lead to overestimated lake volume gains in the two lakes. The example around Kusai shows that multiple altimeters are useful in identifying the cause and effect of a lake outburst.

\section{CONCLUSION}

We used four altimeters: C2, SA, ICESat, and J2, to examine lake level changes in the TP. The C2's SARIn mode results in reliable lake level changes over a large number of lakes. Some of the rates of lake level change from $\mathrm{C} 2$ have been confirmed by the result from SA. A high spatial resolution of $\mathrm{C} 2$ can compensate for the deficiency in its temporal coverage, especially for the lakes with large areas that can be visited by a satellite like $\mathrm{C} 2$ during its 30 -day sub-cycles. $\mathrm{C} 2$ has extended the lake level records from ICESat and repeat missions such as T/P and Jason-1 in some lakes, helping to understand the dominant contributing factors to the long-term lake level and climate changes in Tibet.

With its relatively small cross-track distance $(7 \mathrm{~km}$ at the equator in one year), $\mathrm{C} 2$ can also detect water exchanges among lakes affected by extreme climatic events such as flooding. This capability was demonstrated over Zhuonai, Kusia, and Salt Lake using the volume losses and gains. Altimeter data from a repeat mission such as SA or J2 cannot achieve this because of its large cross-track spacing. Furthermore, the potential post-2016 lake level declines seen in many large lakes in the TP can be investigated using ongoing and future altimeter and GRACE data. It will be interesting to see whether such declining trends are transient or will continue into the next decade. This study shows the benefit of multiple altimeters for determining and cross-validating long term and episodic lake level changes in the TP.

Acknowledgements This study is supported by MOST/ Taiwan Grants 106-2221-E-009-133-MY3, 106-2611-M009 -001, and NSFC/mainland China Grants 41429401 and 41571068 . We are grateful to JF Crétaux for comments on an earlier version of this paper. We thank AVISO and NASA/JPL for providing the altimeter data in this study and the Tibetan students who identified the Tibetan lake names in Appendix A.

\section{REFERENCES}

Biskop, S., F. Maussion, P. Krause, and M. Fink, 2016: Differences in the water-balance components of four lakes in the southern-central Tibetan Plateau. Hydrol. Earth Syst. Sci., 20, 209-225, doi: 10.5194/hess-20209-2016. [Link]

Bouzinac, C., 2013: CryoSat Product Handbook, ESA, UCL, $150 \mathrm{pp}$. Available at https://earth.esa.int/documents/10174/125272/CryoSat Product Handbook.

Chao, N., Z. Wang, C. Hwang, T. Jin, and Y. S. Cheng,

Table 3. Volume changes of three lakes due to the 2011 lake outburst (unit: $\mathrm{km}^{3}$ ).

\begin{tabular}{cccc}
\hline ID & Lake & Volume change (Method 1) & Volume change (Method 2) \\
\hline 52 & Zhuonai Lake & -2.5287 & -2.5558 \\
55 & Kusai Lake & 1.8233 & 1.8256 \\
56 & Salt Lake & 1.2605 & 1.3092 \\
\hline & Sum & 0.5551 & 0.5790 \\
\hline
\end{tabular}


2017: Decline of Geladandong Glacier Elevation in Yangtze River's Source Region: Detection by ICESat and Assessment by Hydroclimatic Data. Rem.Sens., 9, 75, doi: 10.3390/rs9010075. [Link]

Crétaux, J. F., S. Calmant, V . Romanovski, A. Shabunin, F. Lyard, M. Bergé-Nguyen, A. Cazenave, F. Hernandez, and F. Perosanz, 2009: An absolute calibration site for radar altimeters in the continental domain: Lake Issykkul in Central Asia. J. Geodesy, 83, 723-735, doi: 10.1007/s00190-008-0289-7. [Link]

Crétaux, J. F., R. Abarca-del-Río, M. Bergé-Nguyen, A. Arsen, V. Drolon, G. Clos, and P. Maisongrande, 2016: Lake volume monitoring from space. Surv. Geophys., 37, 269-305, doi: 10.1007/s10712-016-9362-6. [Link]

Fu, L. L. and B. J. Haines, 2013: The challenges in longterm altimetry calibration for addressing the problem of global sea level change. Adv. Space Res., 51, 12841300, doi: 10.1016/j.asr.2012.06.005. [Link]

Gao, L., J. Liao, and G. Shen, 2013: Monitoring lake-level changes in the Qinghai-Tibetan Plateau using radar altimeter data (2002-2012). J. Appl. Remote Sens., 7, 073470, doi: 10.1117/1.JRS.7.073470. [Link]

Huang, W., J. Liao, and G. Shen, 2012: Lake change in past 40 years in the southern Nagqu district of Tibet and analysis of its driving forces. Remote Sensing for Land $\&$ Resources, 24, 122-128. (in Chinese)

Hwang, C., M. F. Peng, J. Ning, J. Luo, and C. H. Sui, 2005: Lake level variations in China from TOPEX/Poseidon altimetry: Data quality assessment and links to precipitation and ENSO. Geophys. J. Int., 161, 1-11, doi: 10.1111/j.1365-246X.2005.02518.x. [Link]

Hwang, C., Y. C. Kao, and N. Tangdamrongsub, 2011: A preliminary analysis of lake level and water storage changes over Lakes Baikal and Balkhash from satellite altimetry and gravimetry. Terr. Atmos. Ocean. Sci., 22, 97-108, doi: 10.3319/TAO.2010.05.19.01(TibXS). [Link]

Hwang, C., Y. S. Cheng, J. Han, R. Kao, C. Y. Huang, S. H. Wei, and H. Wang, 2016: Multi-decadal monitoring of lake level changes in the Qinghai-Tibet Plateau by the TOPEX/Poseidon-family altimeters: Climate implication. Rem. Sens., 8, 446, doi: 10.3390/rs8060446. [Link]

Immerzeel, W. W., L. P. H. van Beek, and M. F. P. Bierkens, 2010: Climate change will affect the Asian water towers. Science, 328, 1382-1385, doi: 10.1126/ science.1183188. [Link]

Jiang, L., K. Nielsen, O. B. Andersen, and P. Bauer-Gottwein, 2017: Monitoring recent lake level variations on the Tibetan Plateau using Cryosat-2 SARIn mode data. J. Hydrol., 544, 109-124, doi: 10.1016/j.jhydrol.2016.11.024. [Link]

Kang, S., Y. Xu, Q. You, W. A. Flügel, N. Pepin, and T. Yao, 2010: Review of climate and cryospheric change in the Tibetan Plateau. Environ. Res. Lett., 5, 015101, doi: 10.1088/1748-9326/5/1/015101. [Link]

Kleinherenbrink, M., R. C. Lindenbergh, and P. G. Ditmar, 2015: Monitoring of lake level changes on the Tibetan Plateau and Tian Shan by retracking Cryosat SARIn waveforms. J. Hydrol., 521, 119-131, doi: 10.1016/j. jhydrol.2014.11.063. [Link]

Kusche, J., R. Schmidt, S. Petrovic, and R. Rietbroek, 2009: Decorrelated GRACE time-variable gravity solutions by GFZ, and their validation using a hydrological model. J. Geodesy, 83, 903-913, doi: 10.1007/s00190-0090308-3. [Link]

Levine, A. F. Z. and M. J. McPhaden, 2016: How the July 2014 easterly wind burst gave the 2015-2016 El Niño a head start. Geophys. Res. Lett., 43, 6503-6510, doi: 10.1002/2016GL069204. [Link]

Liao, J., G. Shen, and Y. Li, 2013: Lake variations in response to climate change in the Tibetan Plateau in the past 40 years. Int. J. Digital Earth, 6, 534-549, doi: 10.1080/17538947.2012.656290. [Link]

Liu, B. K., L. Lin, Y. Du, T. Liang, S. Duan, F. Hou and J. Ren, 2016: Causes of the outburst of Zonag Lake in Hoh Xil, Tibetan Plateau, and its impact on surrounding environment. J. Glaciol. Geocryology, 38, 305311. (in Chinese)

Liu, Z., 2012: Dynamics of interdecadal Climate Variability: A Historical Perspective. J. Climate, 25, 19631995, doi: 10.1175/2011JCLI3980.1 . [Link]

Navarra, A., 1999: Beyond El Niño: Decadal and Interdecadal Climate Variability, Springer-Verlag Berlin Heidelberg, Berlin, 375 pp, doi: 10.1007/978-3-64258369-8. [Link]

Pavlis, N. K., S. A. Holmes, S. C. Kenyon, and J. K. Factor, 2012: The development and evaluation of the Earth Gravitational Model 2008 (EGM2008).J. Geophys.Res., 117, B04406, doi: 10.1029/2011JB008916. [Link]

Shao, Z., X. Meng, D. Zhu, D. Zheng, Z. Qiao, C. Yang, J. Han, J. Yu, Q. Meng, and R. Lü, 2008: Characteristics of the change of major lakes on the Qinghai-Tibet Plateau in the last 25 years. Front. Earth Sci. China, 2, 364-377, doi: 10.1007/s11707-008-0038-5. [Link]

Song, C., Q. Ye, and X. Cheng, 2015: Shifts in water-level variation of Namco in the central Tibetan Plateau from ICESat and CryoSat-2 altimetry and station observations. Sci. Bull., 60, 1287-1297, doi: 10.1007/s11434015-0826-8. [Link]

Tapley, B. D., S. Bettadpur, J. C. Ries, P. F. Thompson, and M. M. Watkins, 2004: GRACE measurements of mass variability in the Earth system. Science, 305, 503-505, doi: 10.1126/science.1099192. [Link]

Tapley, B., F. Flechtner, M. Watkins, and S. Bettadpur, 2015: GRACE mission: Status and prospects. Presented at: Grace Science Team Meeting 2015, Austin, Texas. 
Taube, C. M., 2000: Three methods for computing the volume of a lake. In: Schneider, J. C. (Ed.), Manual of Fisheries Survey Methods II: With Periodic Updates, Lansing, State of Michigan, United States of America: Michigan Department of Natural Resources.

Tseng, K. H., C. P. Chang, C. Shum, C. Y. Kuo, K. T. Liu, K. Shang, Y. Jia, and J. Sun, 2016: Quantifying freshwater mass balance in the central Tibetan plateau by integrating satellite remote sensing, altimetry, and gravimetry. Rem. Sens., 8, 441, doi: 10.3390/rs8060441. [Link]

$\mathrm{Xu}, \mathrm{H} ., 2006$ : Modification of normalised difference water index (NDWI) to enhance open water features in remotely sensed imagery. Int. J. Remote Sens., 27, 30253033, doi: 10.1080/01431160600589179. [Link]

Yang, K., H. Lu, S. Yue, G. Zhang, Y. Lei, Z. La, and W. Wang, 2018: Quantifying recent precipitation change and predicting lake expansion in the Inner Tibetan Plateau. Clim. Change, 147, 149-163, doi: 10.1007/ s10584-017-2127-5. [Link]

Yang, Y., C. Hwang, H. J. Hsu, E. Dongchen, and H. Wang, 2012: A subwaveform threshold retracker for ERS-1 altimetry: A case study in the Antarctic Ocean. Comput. Geosci., 41, 88-98, doi: 10.1016/j.cageo.2011.08.017. [Link]

Yao, X., S. Liu, L. Li, M. Sun, J. Luo, and Y. Feng, 2013: Spatial-temporal variations of lake area in Hoh Xil region in the past 40 years. Acta Geogr. Sin., 68, 886896. (in Chinese)

Zhai, P., R. Yu, Y. Guo, Q. Li, X. Ren, Y. Wang, W. Xu, Y. Liu, and Y. Ding, 2016: The strong El Niño of 2015/16 and its dominant impacts on global and China's climate. J. Meteorol. Res., 30, 283-297, doi: 10.1007/ s13351-016-6101-3. [Link]

Zhang, G., H. Xie, S. Kang, D. Yi, and S. F. Ackley, 2011: Monitoring lake level changes on the Tibetan Plateau using ICESat altimetry data (2003-2009). Remote Sens. Environ., 115, 1733-1742, doi: 10.1016/j. rse.2011.03.005. [Link]

Zhang, G., T. Yao, H. Xie, S. Kang, and Y. Lei, 2013: Increased mass over the Tibetan Plateau: From lakes or glaciers? Geophys. Res. Lett., 40, 2125-2130, doi: 10.1002/grl.50462. [Link]

Zhang, G., T. Yao, H. Xie, K. Zhang, and F. Zhu, 2014: Lakes' state and abundance across the Tibetan Plateau. Chin. Sci. Bull., 59, 3010-3021, doi: 10.1007/s11434014-0258-x. [Link]

Zhang, G., T. Yao, S. Piao, T. Bolch, H. Xie, D. Chen, Y. Gao, C. M. O'Reilly, C. K. Shum, K. Yang, S. Yi, Y. Lei, W. Wang, Y. He, K. Shang, X. Yang, and H. Zhang, 2017a: Extensive and drastically different alpine lake changes on Asia's high plateaus during the past four decades. Geophys. Res. Lett., 44, 252-260, doi: 10.1002/2016GL072033. [Link]

Zhang, G., T. Yao, C. K. Shum, S. Yi, K. Yang, H. Xie, W. Feng, T. Bolch, L. Wang, A. Behrangi, H. Zhang, W. Wang, Y. Xiang, and J. Yu, 2017b: Lake volume and groundwater storage variations in Tibetan Plateau's endorheic basin. Geophys. Res. Lett., 44, 5550-5560, doi: 10.1002/2017GL073773. [Link]

Zhang, X., Y. Wu, and X. Zhang, 2015: Zhari namco water level change detection using multi-satellite altimetric data during 1992-2012. J. Nat. Resour., 30, 11531162, doi: 10.11849/zrzyxb.2015.07.008. (in Chinese) [Link]

\section{APPENDIX A: SELECTED INFORMATION ABOUT THE STUDIED LAKES}

Table A1. The following table shows selected information about the lakes where trends of lake levels are derived from Cryosat-2 and SARAL/ AltiKa. Lake names are given in Chinese, English, and Tibetan (except Aksayqin Lake).

\begin{tabular}{|c|c|c|c|c|c|c|}
\hline ID & Lake & Latitude $\left({ }^{\circ}\right)$ & Longitude $\left({ }^{\circ}\right)$ & Area $\left(\mathbf{k m}^{2}\right)$ & Mean height (m) & Altimeter \\
\hline 1 & 阿克賽欽 / Aksayqin Lake & 35.17 & 79.85 & 174.3 & 4850 & $\mathrm{C} 2^{1}$ \\
\hline 2 & 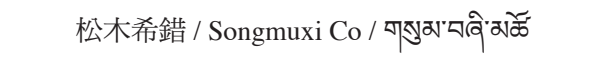 & 34.59 & 80.23 & 27.2 & 5057 & $\mathrm{C} 2$ \\
\hline 3 & 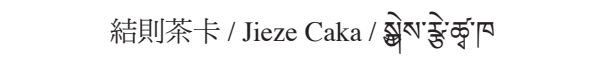 & 33.95 & 80.90 & 107.6 & 4530 & $\mathrm{C} 2 / \mathrm{SA}^{2}$ \\
\hline 4 & 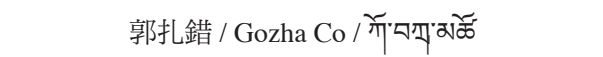 & 35.02 & 81.06 & 252.6 & 5086 & $\mathrm{C} 2$ \\
\hline 5 & 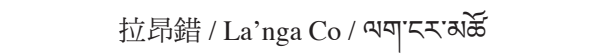 & 30.65 & 81.24 & 268.5 & 4570 & $\mathrm{C} 2 / \mathrm{SA}$ \\
\hline 6 & 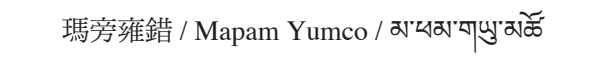 & 30.72 & 81.47 & 412 & 4590 & $\mathrm{C} 2 / \mathrm{SA}$ \\
\hline 7 & 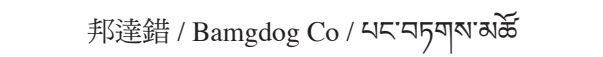 & 34.94 & 81.55 & 106.5 & 4909 & $\mathrm{C} 2 / \mathrm{SA}$ \\
\hline 8 & 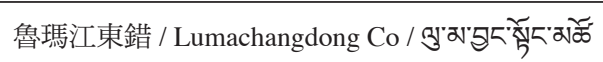 & 34.04 & 81.62 & 351.6 & 4818 & $\mathrm{C} 2 / \mathrm{SA}$ \\
\hline 9 & 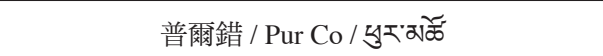 & 34.88 & 81.96 & 40.12 & 5054 & $\mathrm{C} 2$ \\
\hline
\end{tabular}

Note: 1: Cryosat-2; 2: SARAL/AltiKa. 
Table A1. (Continued)

\begin{tabular}{|c|c|c|c|c|c|c|}
\hline ID & Lake & Latitude $\left({ }^{\circ}\right)$ & Longitude $\left({ }^{\circ}\right)$ & Area $\left(\mathbf{k m}^{2}\right)$ & Mean height (m) & Altimeter \\
\hline 10 & 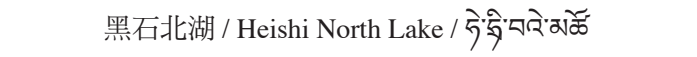 & 35.55 & 82.75 & 93 & 5055 & $\mathrm{C} 2 / \mathrm{SA}$ \\
\hline 11 & 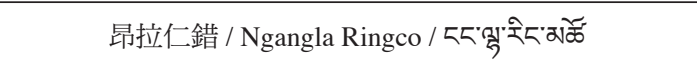 & 31.54 & 82.99 & 512.7 & 4721 & $\mathrm{C} 2 / \mathrm{SA}$ \\
\hline 12 & 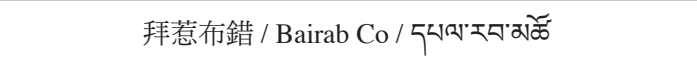 & 34.99 & 83.07 & 128.8 & 4966 & $\mathrm{C} 2$ \\
\hline 13 & 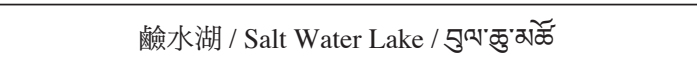 & 35.29 & 83.12 & 88.9 & 4894 & $\mathrm{C} 2$ \\
\hline 14 & 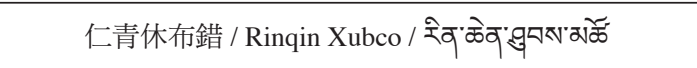 & 31.28 & 83.46 & 187.1 & 4765 & $\mathrm{C} 2$ \\
\hline 15 & 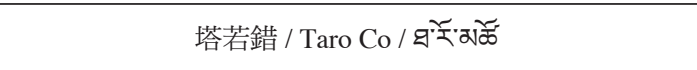 & 31.14 & 84.12 & 486.6 & 4572 & $\mathrm{C} 2 / \mathrm{SA}$ \\
\hline 16 & 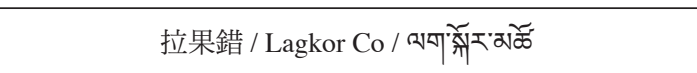 & 32.02 & 84.12 & 91.2 & 4472 & $\mathrm{C} 2$ \\
\hline 17 & 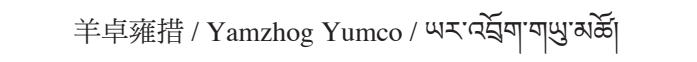 & 35.42 & 84.64 & 90 & 4783 & $\mathrm{C} 2$ \\
\hline 18 & 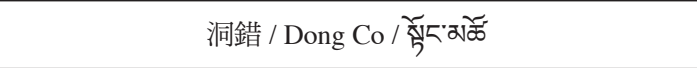 & 32.18 & 84.74 & 123.5 & 4399 & $\mathrm{C} 2 / \mathrm{SA}$ \\
\hline 19 & 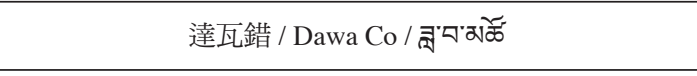 & 31.24 & 84.96 & 114.4 & 4628 & $\mathrm{C} 2$ \\
\hline 20 & 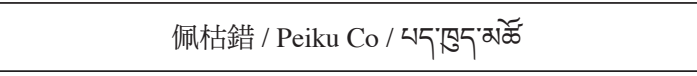 & 28.83 & 85.6 & 284.4 & 4585 & $\mathrm{C} 2$ \\
\hline 21 & 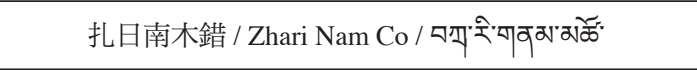 & 30.93 & 85.6 & 996.9 & 4617 & $\mathrm{C} 2 / \mathrm{SA}$ \\
\hline 22 & 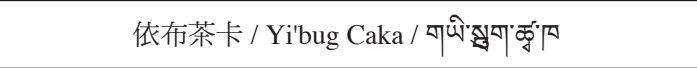 & 32.86 & 86.66 & 88 & 4563 & $\mathrm{C} 2$ \\
\hline 23 & 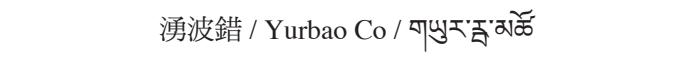 & 35.74 & 86.72 & 58.2 & 4887 & $\mathrm{C} 2$ \\
\hline 24 & 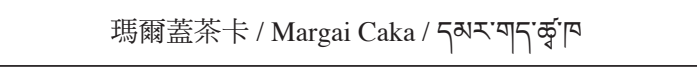 & 35.12 & 86.77 & 79.6 & 4798 & $\mathrm{C} 2$ \\
\hline 25 & 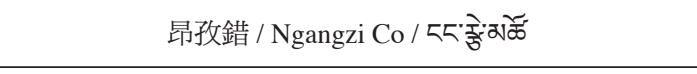 & 31.02 & 87.12 & 461.5 & 4690 & $\mathrm{C} 2 / \mathrm{SA}$ \\
\hline 26 & 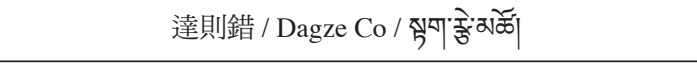 & 31.89 & 87.54 & 244.7 & 4470 & $\mathrm{C} 2 / \mathrm{SA}$ \\
\hline 27 & 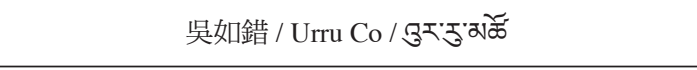 & 31.71 & 88.01 & 342.7 & 4559 & $\mathrm{C} 2$ \\
\hline 28 & 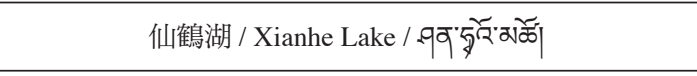 & 35.99 & 88.09 & 33.4 & 4846 & $\mathrm{C} 2$ \\
\hline 29 & 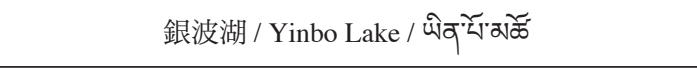 & 36.19 & 88.13 & 30.4 & 4882 & $\mathrm{C} 2$ \\
\hline 30 & 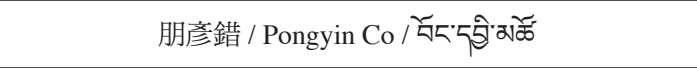 & 32.89 & 88.19 & 48.8 & 4732 & $\mathrm{C} 2$ \\
\hline 31 & 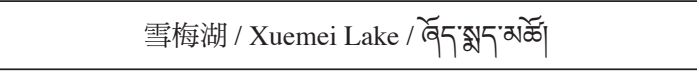 & 36.27 & 88.25 & 33.5 & 4878 & $\mathrm{C} 2 / \mathrm{SA}$ \\
\hline 32 & 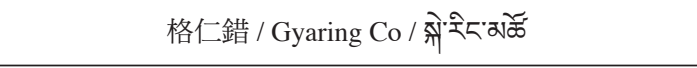 & 31.04 & 88.45 & 475.9 & 4654 & $\mathrm{C} 2 / \mathrm{SA}$ \\
\hline 33 & 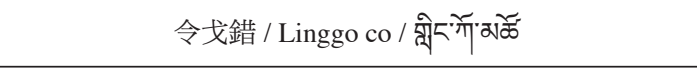 & 33.85 & 88.59 & 89 & 5068 & $\mathrm{C} 2$ \\
\hline 34 & 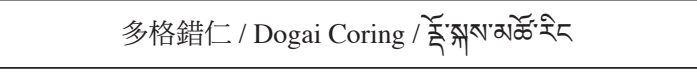 & 34.57 & 88.99 & 393.3 & 4823 & $\mathrm{C} 2 / \mathrm{SA}$ \\
\hline 35 & 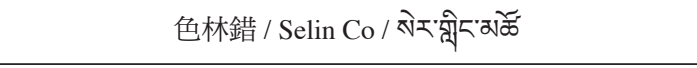 & 31.81 & 89.01 & 2391 & 4544 & $\mathrm{C} 2 / \mathrm{SA}$ \\
\hline 36 & 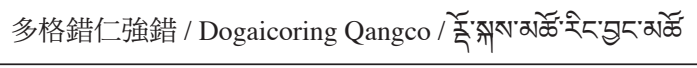 & 35.32 & 89.20 & 207.5 & 4792 & $\mathrm{C} 2 / \mathrm{SA}$ \\
\hline 37 & 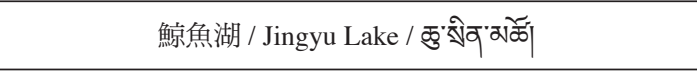 & 36.35 & 89.38 & 320.33 & 4718 & $\mathrm{C} 2 / \mathrm{SA}$ \\
\hline 38 & 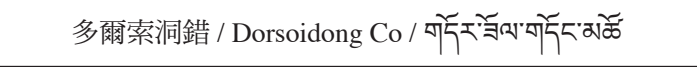 & 33.38 & 89.86 & 400 & 4935 & $\mathrm{C} 2 / \mathrm{SA}$ \\
\hline 39 & 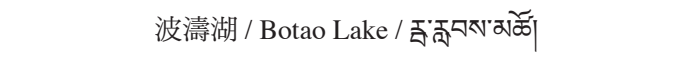 & 34.00 & 89.95 & 70.9 & 4994 & $\mathrm{C} 2$ \\
\hline 40 & 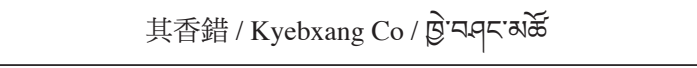 & 32.44 & 89.98 & 149 & 4620 & $\mathrm{C} 2$ \\
\hline 41 & 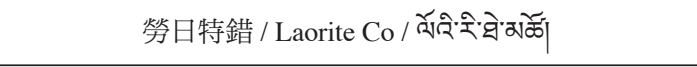 & 33.72 & 90.03 & 57.3 & 4955 & $\mathrm{C} 2$ \\
\hline 42 & 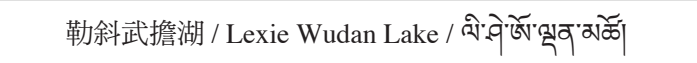 & 35.74 & 90.18 & 231.2 & 4875 & $\mathrm{C} 2 / \mathrm{SA}$ \\
\hline
\end{tabular}


Table A1. (Continued)

\begin{tabular}{|c|c|c|c|c|c|c|}
\hline ID & Lake & Latitude $\left({ }^{\circ}\right)$ & Longitude $\left({ }^{\circ}\right)$ & Area $\left(\mathbf{k m}^{2}\right)$ & Mean height (m) & Altimeter \\
\hline 43 & 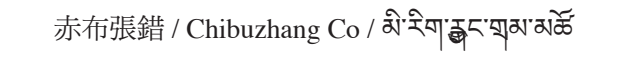 & 33.46 & 90.21 & 476.8 & 4941 & $\mathrm{C} 2 / \mathrm{SA}$ \\
\hline 44 & 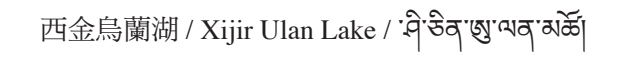 & 35.20 & 90.34 & 530 & 4780 & $\mathrm{C} 2$ \\
\hline 45 & 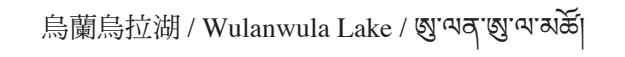 & 34.75 & 90.39 & 610 & 4777 & $\mathrm{C} 2 / \mathrm{SA}$ \\
\hline 46 & 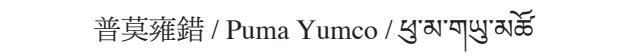 & 28.56 & 90.40 & 295 & 5019 & $\mathrm{C} 2 / \mathrm{SA}$ \\
\hline 47 & 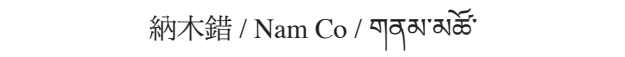 & 30.71 & 90.53 & 1920 & 4729 & $\mathrm{C} 2 / \mathrm{SA}$ \\
\hline 48 & 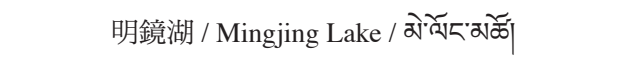 & 35.06 & 90.54 & 121.2 & 4802 & $\mathrm{C} 2 / \mathrm{SA}$ \\
\hline 49 & 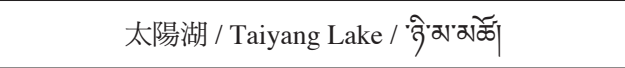 & 35.92 & 90.63 & 99.8 & 4886 & $\mathrm{C} 2$ \\
\hline 50 & 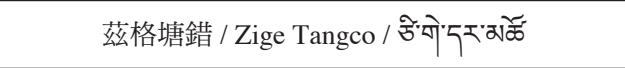 & 32.06 & 90.84 & 191.4 & 4573 & $\mathrm{C} 2$ \\
\hline 51 & 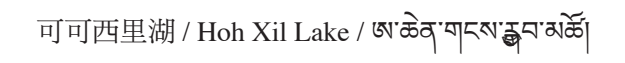 & 35.58 & 91.15 & 347.3 & 4892 & $\mathrm{C} 2$ \\
\hline 52 & 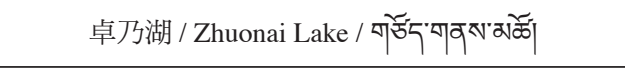 & 35.54 & 91.93 & 51 & 4758 & $\mathrm{C} 2$ \\
\hline 53 & 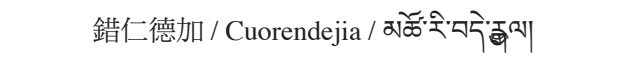 & 35.21 & 92.20 & 192.3 & 4693 & $\mathrm{C} 2 / \mathrm{SA}$ \\
\hline 54 & 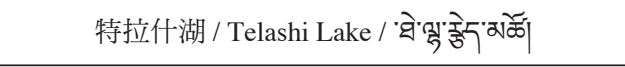 & 34.80 & 92.21 & 54.1 & 4810 & $\mathrm{C} 2$ \\
\hline 55 & 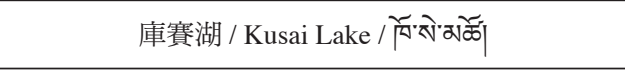 & 35.69 & 92.92 & 336.17 & 4480 & $\mathrm{C} 2 / \mathrm{SA}$ \\
\hline 56 & 鹽湖 / Salt Lake / б̆ğ & 35.52 & 93.40 & 124.9 & 4450 & $\mathrm{C} 2$ \\
\hline 57 & 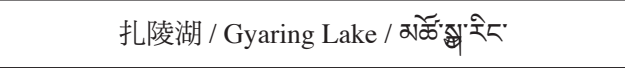 & 34.93 & 97.27 & 526 & 4295 & $\mathrm{C} 2 / \mathrm{SA}$ \\
\hline 58 & 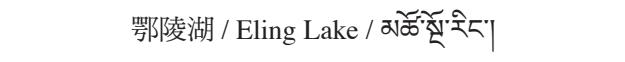 & 34.88 & 97.68 & 610 & 4272 & $\mathrm{C} 2 / \mathrm{SA}$ \\
\hline 59 & 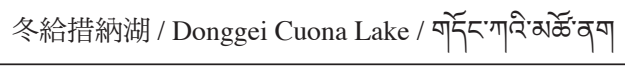 & 35.26 & 98.60 & 226.5 & 4270 & $\mathrm{C} 2$ \\
\hline 60 & 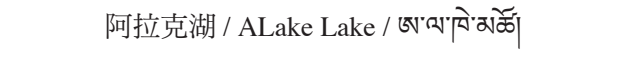 & 35.56 & 97.13 & 47 & 4110 & SA \\
\hline 61 & 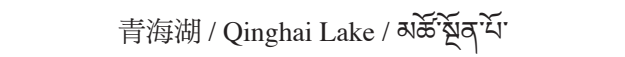 & 36.76 & 100.35 & 4186 & 3198 & SA \\
\hline
\end{tabular}

